\title{
NUMERICAL STUDIES ON SMOKE SPREAD IN THE CAVITY OF A DOUBLE-SKIN FAÇADE
}

\author{
Cheuk Lun Chow \\ Department of Architecture, Wolfson College, University of Cambridge, \\ Barton Road, Cambridge CB3 9BB, UK \\ E-mail:nadiaclc@yahoo.com.hk \\ Received 13 Aug. 2010; accepted 08 Nov. 2010
}

\begin{abstract}
Double-skin façade (DSF) is an environmental friendly architectural feature. However, fire hazard is a concern. A scenario of having a flashover room fire adjacent to the façade was identified. Heat and mass would be trapped in the façade cavity. This paper examines air flow driven out of a flashover room fire to the cavity of a DSF by Computational Fluid Dynamics. The software Fire Dynamics Simulator developed at the Building and Fire Research laboratory, National Institute of Standards and Technology, USA was selected as the simulation tool. Three DSF features labeled as DSF1, DSF2 and DSF3 were considered. Detailed simulations were carried out to understand the fire-induced aerodynamics in a 5-level model DSF1 with a fire room at the third level. Hot gas spreading out to the façade cavity was simulated under two heat release rates of $1 \mathrm{MW}$ and $5 \mathrm{MW}$. Air cavity depths of $0.5 \mathrm{~m}, 1 \mathrm{~m}, 1.5 \mathrm{~m}$ and $2 \mathrm{~m}$ were considered. Three stages of flame spreading out to a DSF with a wide air cavity depth were identified. Results suggested that wider air cavity depths would be more dangerous, with higher risk of the upper interior glass pane's breaking. To study spreading of heat and mass up the façade cavity as vertical channel flow, two taller DSF façade features DSF2 and DSF3 with differing air cavity depths were simulated. Both features were of height $24 \mathrm{~m}$ but of differing fire room height. Vertical temperature profiles with and without the DSF feature were compared.
\end{abstract}

Keywords: double-skin façade, air cavity, smoke spread.

\section{Introduction}

Glass façade buildings are popular in developing cities. Double-skin façade (DSF) is proposed (Lstiburek 2008) for building energy conservation. However, many new projects (Chow 2003) with a DSF have difficulties to comply with the fire regulations. Additional fire safety provisions are required, but there is no international rule. Fire safety for the DSF should be dealt with most carefully (Chow et al. 2009). The behaviour of glass panels on adjacent upper interior and exterior panes in a flashover fire depend on the flame and smoke spread from the fire compartment. Though glass is a non-combustible material, it will be weakened when heated to about $295^{\circ} \mathrm{C}$ (Glass and Glazing Federation 1978). Moreover, as a poor conductor, heat is difficult to transfer in a glass pane from the area exposed to the fire to the other region. The temperature difference between these hot and cool regions will induce thermal expansion. When tensile stress reaches its critical value, cracking will occur (Hassani et al. 1995). The aluminum frame of windows, even more frail than glass, will be weakened when heated up to $200{ }^{\circ} \mathrm{C}$ and melt at about $550{ }^{\circ} \mathrm{C}$. Its severe distortion induces stresses across the glass plate held up by the frame. Even worse, the whole piece of glass will fall out (Hassani et al. 1995; Morris 1999; Jackman and Finegan 2001). A single glazing would probably break and fall out under certain conditions, say about $400{ }^{\circ} \mathrm{C}$ to cause fallout of $6 \mathrm{~mm}$ clear float glass (Shields et al. 2002).

For an ordinary single-skin curtain wall, smoke and toxic gases can be diluted and cooled down by the ambient air. But with a DSF, hot gases are trapped inside the vertical air cavity which is at higher temperature than in the open space. In addition, pressure developed inside the cavity sometimes determines the moment of breaking of the glass pane. If the interior glass pane of a DSF is broken by a post-flashover fire, smoke and flame moving out to the cavity would spread to the upper part of the building. As identified before (Chow 2009; Ding et al. 2005; Chow and Hung 2006), a scenario with a flashover room fire occurred adjacent to the DSF is hazardous. Smoke, heat and even flame are trapped inside the façade cavity. The consequence will be very serious when the interior glass panels are broken. Consequently, many projects with DSF fail to comply with the fire regulations in Hong Kong as reported (Chow 2003, 2009).

There are requirements on testing fire resistance of curtain walling in some countries, e.g. EN-13501 (British Standards Institution 2007). Part of the façade would be tested with a standard furnace on integrity, insulation and radiation on assessing post-fire behaviour. However, such tests cannot evaluate the identified scenario on spread of heat and smoke in the façade cavity. 
If a flashover room fire occurred next to the façade, the piece of interior glass pane (but not those panes at positions above it) can be easily broken due to direct exposure to thermal radiation. Note that the heat flux at the wall for onsetting flashover is $35 \mathrm{kWm}^{-2}$. Flame and smoke would come out of the resultant opening. The exterior glass pane might be cracked or even broken by heat as in Fig. 1a. Another possibility is that the upper interior glass pane would break if smoke or flame moves upwards, as in Fig. 1c after detaching from the exterior pane as shown in Fig. 1b. Detailed analysis on the flame shape and bending while moving out due to a flashover fire should be included in hazard assessment.

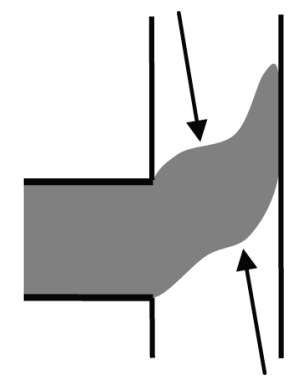

Air entrainment from below

a) Initial

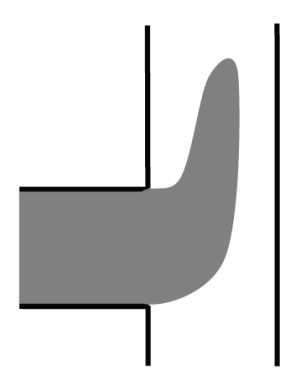

b) Detached from exterior pane

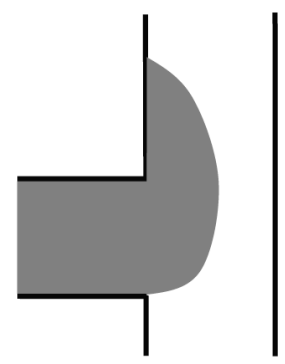

c) Adhered to the interior pane

Fig. 1. Possible mechanisms of flame bending

Breakage of the exterior glass pane would carry a lower fire risk because hot smoke can be diverted out. However, breaking the upper interior glass pane is disastrous, providing a flow channel for spreading of smoke and flame to upper stories. Exact understanding of the thermal performance of the glass panels on the adjacent floors and on the exterior glass pane is vital. Temperature differences between the interior and exterior glass panes have to be known to determine which pane would be broken first.
In this paper, Computational Fluid Dynamics (CFD) (Chow 1995) will be applied to study the fire-induced air flow spreading out from a compartment to the cavity of a DSF feature. The CFD package Fire Dynamics Simulator (FDS) (McGrattan 2006; McGrattan and Forney 2005) developed at the Building and Fire Research laboratory, National Institute of Standards and Technology, USA was applied to study how hot gas from a flashover fire in an adjacent room spreads to the cavity of the DSF. Detailed simulations were carried out to understand the fire-induced aerodynamics in the façade cavity of heights up to $15 \mathrm{~m}$.

Investigation using CFD on the fire behavior of DSF is the first step. Temperature distribution on the interior and exterior glass panes can be predicted. Smoke movement pattern suggested earlier as shown in Fig. 1 can then be justified. The critical part is the separation distance of the two panels, i.e. the cavity depth. CFD results on the fire-induced air flow from a room fire to a DSF on the air flow would give some indication on the spreading mechanism.

\section{Design fire}

As the types and amount of combustibles stored in a room vary, it is difficult to estimate the possible heat release rate. Many types of combustibles are stored in a room. Chemical data is difficult to compile for modeling the combustion process even if the types and amounts of fuel are known. In a room of normal size and opening provisions as the room calorimeter in standard fire test, the minimum heat release rate for onsetting flashover is about $1 \mathrm{MW}$. Therefore, such a fire is assumed with heat distributed in a burning $1 \mathrm{~m}$ cubic object. A heat source of constant heat flux emitted per unit fuel area was taken as the fire in the following CFD simulations. This will allow easier comparison on the heat and mass spread out from the fire room to the façade cavity under different geometrical configurations such as cavity depths and building heights for fire simulations as in this chapter. Similar approach had been applied to study external protrusions in tall buildings (Galea et al. 1996). There are proposals on specifying a fire with heat release rate distributed uniformly up to the flame height (Kumar 2009; Kumar et al. 2010). The horizontal flame length would be included for rooms of low ceiling height. Such approaches without detailed combustion phenomena need to be justified by experiments. Similar CFD results were predicted by specifying the fire either as a constant volumetric heat source or as a source of emitting heat flux.

A low heat release rate of $1 \mathrm{MW}$ is normally not accepted by the authority in fire hazard assessment in performance-based design such as providing active protection systems on refuge floor as explained before (Chow and Chow 2009a). A common practice in the Far East such as Hong Kong is to use a design fire of $5 \mathrm{MW}$. Therefore, two heat sources of $1 \mathrm{MW}$ and $5 \mathrm{MW}$ with constant heat flux per unit area were used as the design fire in the simulations of this paper. Thermally-induced air flow through the façade cavity of the DSF will be simulated by CFD-FDS. 


\section{Numerical studies}

A 5-level DSF model DSF1 of height $15 \mathrm{~m}$ and width $6 \mathrm{~m}$ as in Fig. 2 was considered. The cavity depth varied, at $0.5 \mathrm{~m}, 1 \mathrm{~m}, 1.5 \mathrm{~m}$ and $2 \mathrm{~m}$. All these values are common design cavity depths for DSF installed in buildings all over the world (Oesterle 2001; Loncour 2004; Streicher et al. 2005; Lstiburek 2008; Sinclair 2009). Burning tests with such cavity depths would give useful information on behaviour of DFS under real fires. Rooms each of length $6 \mathrm{~m}$ and height $3 \mathrm{~m}$ are located adjacent to the DSF. A fire was assumed to occur in a room of length $6 \mathrm{~m}$ at the far end of the third level of size $1 \mathrm{~m}$ by $1 \mathrm{~m}$ by $1 \mathrm{~m}$ and heat release rate $1 \mathrm{MW}$ or $5 \mathrm{MW}$. The fire is taken as a heat source emitting $1000 \mathrm{~kW}$ or $5000 \mathrm{~kW}$ over the area of $1 \mathrm{~m}$ by $1 \mathrm{~m}$ located $1 \mathrm{~m}$ above the floor. The interior glass pane next to the room was broken to give an opening $6 \mathrm{~m}$ wide and $3 \mathrm{~m}$ tall. A ceiling jet was then driven by the fire to move out of the room from the opening. The two levels below and above the fire room are taken as obstruction objects as the interior panes next to these four rooms are not broken. FDS was used to study the air motion and heat transfer.

The computing domain was up to $10 \mathrm{~m}$ long, $6 \mathrm{~m}$ wide and $15 \mathrm{~m}$ tall. There are hardware limitations in getting a powerful computer while starting the work in 2005. The domain geometry was divided up to 384,000 parts, i.e. 80, 40, and 120 along the $x-, y-$ and $z-$ (along the gravity) directions as in Fig. 3. Transient results on air flow pattern at the early stage, up to $20 \mathrm{~s}$ only, were shown to capture the initial spreading out of the compartment to the cavity.

Two convergence criteria were adopted as in FDS, the Courant-Friedrichs-Lewy (CFL) criterion and the Von Neumann criterion (McGrattan 2006; McGrattan and Forney 2005). In this paper, the CFL criterion (Courant et al. 1967; Lax 1967) was used to determine convergence.
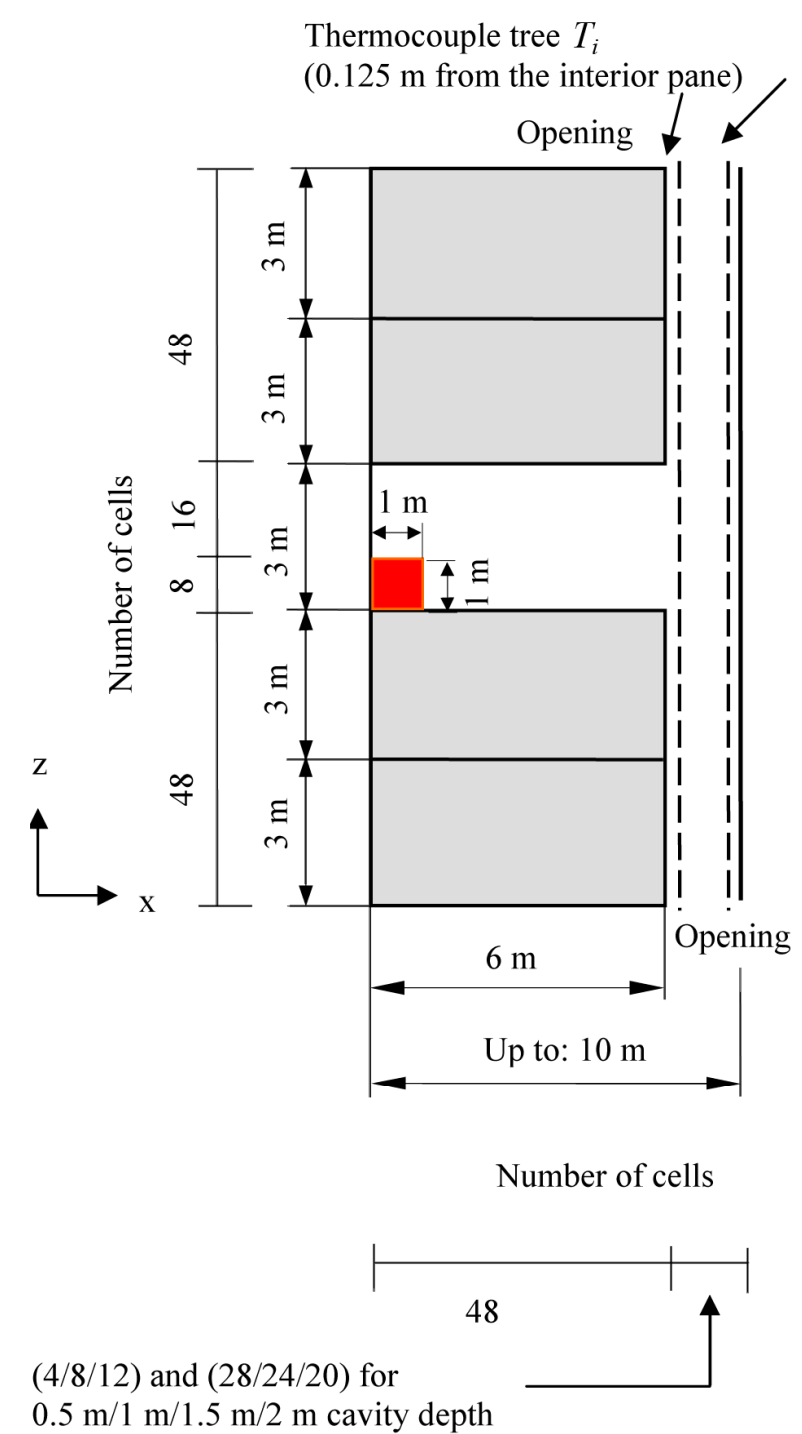

a) Elevation

$(4 / 8 / 12)$ and $(28 / 24 / 20)$ for $0.5 \mathrm{~m} / 1 \mathrm{~m} / 1.5 \mathrm{~m} / 2 \mathrm{~m}$ cavity depth
Thermocouple tree $T_{e}$ $(0.125 \mathrm{~m}$ from the exterior pane)

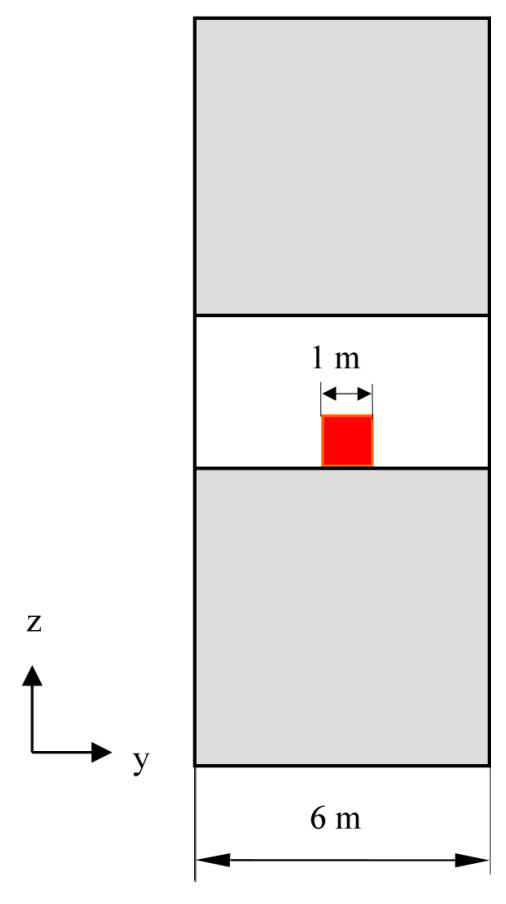

Number of cells

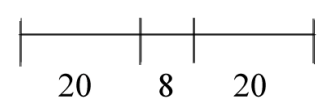


The estimated velocities $u_{i j k}, v_{i j k}$ and $w_{i j k}$ along the $x$-, $y$ and $z$-directions with grid size $\Delta x, \Delta y, \Delta z$ at cell $(i, j, k)$ are tested at each time step $\Delta t$ to ensure that the following condition on maximum value of the ratio of each velocity component magnitude to grid size $\left(\left|u_{i j k}\right| / \Delta x\right)$ along each is satisfied (McGrattan 2006; McGrattan and Forney 2005):

$$
\Delta t * \operatorname{Max}\left(\left|u_{i j k}\right| / \Delta x,\left|v_{i j k}\right| / \Delta y,\left|w_{i j k}\right| / \Delta z\right)<1,
$$

for grid size finer than $5 \mathrm{~mm}$, another criteria will be checked though the viscosity $v$.

$$
2 \Delta t v\left(1 / \Delta x^{2}+1 / \Delta y^{2}+/ 1 \Delta z^{2}\right) .
$$

The initial time step size can be specified in the FDS input file through the parameter DT. It can also be set automatically by dividing the size of a grid cell by the characteristic velocity of the flow. In computation, the time step would be adjusted to satisfy condition (1). The default value of DT is estimated in terms of the dimensions of the smallest grid cell $\Delta x_{m}, \Delta y_{m}$ and $\Delta z_{m}$, the height of the computational domain $\mathrm{H}$, and acceleration due to gravity g:

$$
\mathrm{DT}=5\left(\Delta x_{m} \Delta y_{m} \Delta z_{m}\right)^{\frac{1}{3}} / \sqrt{g H} .
$$

If the CFL condition is not satisfied, the time step is then set to 0.8 of its allowed maximum value. The estimated velocities would be estimated with the CFL condition checked again.

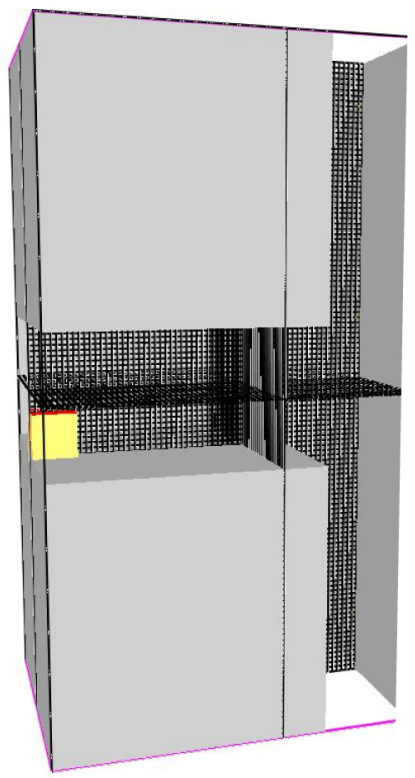

a) Isometric view
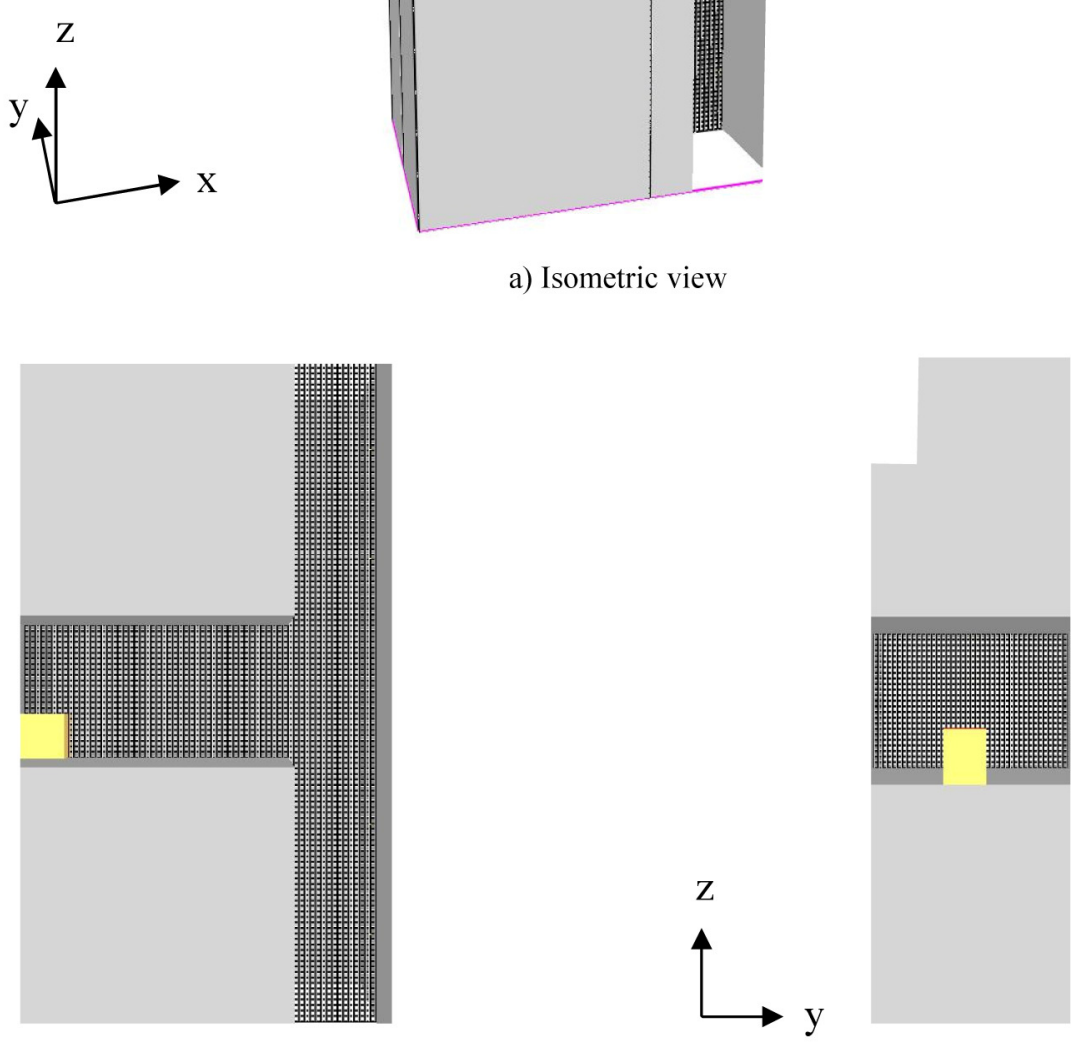

b) Elevation

c) End view

Fig. 3. Grid system of DSF1 for 2 m cavity in FDS simulation 
Results at the first $20 \mathrm{~s}$ for cavity depth of $2 \mathrm{~m}$ and $1 \mathrm{MW}$ fire are shown in Figs 4 and 5. As observed, a ceiling jet was induced by the fire and moved out of the compartment with horizontal momentum. Hot smoke impinged at the exterior pane from $6 \mathrm{~s}$ to $8 \mathrm{~s}$. Horizontal motion was then blocked and the gas flow directed downward at $6 \mathrm{~s}$ as in Fig. 4c. Momentum of downward flow was reduced due to gravity and re-entrained back to the ceiling jet. Upward motion was observed with momentum increased as shown by results at $8 \mathrm{~s}$ in Fig. $4 \mathrm{~d}$. Upward motion along the exterior pane decreased clearly at $10 \mathrm{~s}$. However, upward hot smoke then detached from the exterior pane at $12 \mathrm{~s}$ due to entrainment at the lower side being stronger than at the upper side. Eventually, gas flow attached to the upper interior pane and flowed along it after $14 \mathrm{~s}$.

Predicted velocity vectors for the cavity depths of $1.5 \mathrm{~m}, 1 \mathrm{~m}$ and $0.5 \mathrm{~m}$ of DSF 1 are shown in Figs 6 to 8 . Velocity vectors and temperature contours initially at $2 \mathrm{~s}$ and $4 \mathrm{~s}$ are similar to those for cavity depth of $2 \mathrm{~m}$ as fire had not yet spread out to the double-skin air cavity. But for cavity depths of $1.5 \mathrm{~m}, 1 \mathrm{~m}$ and $0.5 \mathrm{~m}$, both upward and downward flows were observed at $6 \mathrm{~s}$ as in Figs $6 \mathrm{c}$, $7 \mathrm{c}$ and $8 \mathrm{c}$ upon the gas flow striking at the exterior pane. Gas flowed upward later due to higher air entrainment from bottom at $8 \mathrm{~s}$ as shown in Figs $6 \mathrm{~d}, 7 \mathrm{~d}$ and $8 \mathrm{~d}$.

Gas moved upward along the cavity of $1.5 \mathrm{~m}$, clearly observed at $10 \mathrm{~s}$ as in Fig. 6e. Eventually, flow detached from the exterior wall and moved along the interior pane upward at $14 \mathrm{~s}$ as in Fig. $6 \mathrm{~g}$. The gas flow patterns are roughly the same initially up to $8 \mathrm{~s}$ for cavity depth of $0.5 \mathrm{~m}$. However, upward channel flow was observed as a vertical channel flow but detachment from exterior pane was not observed so clearly as in Figs 8g and h. Accordingly, after acting at the exterior pane, detachment from exterior pane was not clearly observed at later time for smaller cavity depth of $0.5 \mathrm{~m}$ as in Figs $8 \mathrm{e}$ to h.

Results for the bigger fire of $5 \mathrm{MW}$ and cavity depths of $2 \mathrm{~m}, 1.5 \mathrm{~m}, 1 \mathrm{~m}$ and $0.5 \mathrm{~m}$ of DSF 1 are also predicted and reported (Chow 2009). Steady burning results are very similar to those of the smaller fire of $1 \mathrm{MW}$ except that the air temperatures were much higher. However, the horizontal momentum of hot gas coming out of the opening induced by a $5 \mathrm{MW}$ fire was much stronger than that by a $1 \mathrm{MW}$ fire, in addition to having higher air temperatures. Hot gas flow was detached from the exterior pane earlier at $6 \mathrm{~s}$ and simply moved up along the interior pane after $10 \mathrm{~s}$ for cavity depths of $2 \mathrm{~m}$ and $1.5 \mathrm{~m}$. But for narrow cavity depths of $0.5 \mathrm{~m}$ and $1 \mathrm{~m}$, detachment flow from the exterior pane was not obvious under this bigger fire. Hot gases would basically flow up along the air cavity as a channel flow, heating up both the exterior and interior panes.

\section{Possible scenario for wide-cavity depth}

The shape of the bent flame outside a vertical façade has been studied in the literature (Seigel 1969; Thomas and Law 1973; Law 1978; Klopovic and Turan 1998). With an additional vertical exterior pane (Bong 2000;
Oleszkiewicz 1989), flame would act on the exterior pane first, depending on the cavity depth.

In view of the above CFD results, the proposed three stages of smoke and flame spreading out from a flashover room fire at a certain level to the DSF as in Fig. 1 with a wide air cavity depth can be deduced as in Fig. 9.

1) Initial stage:

Flame and smoke act on the exterior pane due to adequate horizontal momentum of the window jet.

2) Detachment from exterior pane:

Flame and smoke detached from exterior pane due to differences in air entrainment above and below the hot window jet.

3) Attachment to the interior pane:

Flame and smoke will eventually adhere to the interior pane due to the stronger air entrainment from below.

Air entrainment rate (Satoh and Kuwahara 1991) above the flame would be less than that below the flame as in Fig. 9a. The flame might be detached from the exterior pane as in Fig. 9b, eventually acting on the interior pane as shown in Fig. 9c. Breaking the interior glass pane would spread hot flame and smoke to the upper level as in Fig. 9d.

\section{Air temperature difference adjacent to the two panes}

Estimation of the air temperature difference $\Delta T$ between the positions next to exterior $T_{e}$ and interior $T_{i}$ panes is critical to determining which pane will be broken first:

$$
\Delta T=T_{i}-T_{e} .
$$

Air flow simulations by CFD as above suggested firstly under a big fire such as $5 \mathrm{MW}$, flame of high temperature moves out (there would be a ceiling jet if flashover does not occur in the compartment). The exterior glass pane will be heated first and to a degree higher than that of the interior pane initially to give negative $\Delta T$. Value of $\Delta T$ will be small for small cavity depths of $0.5 \mathrm{~m}$ or $1 \mathrm{~m}$. But both panes are heated to give high $T_{i}$ and $T_{e}$. The time to the first crack and the time the glass falling down are reported in the literature to be very close. It is possible that the exterior pane will break first in the case of small-cavity depths.

Secondly, under a small fire, say $1 \mathrm{MW}$, momentum of the flame flowing out would not be so high but still act at the exterior pane. For large-cavity depth of $2 \mathrm{~m}$, the flame will detach from the exterior pane later due to higher downward air entrainment and bend upward to the upper part of the interior pane. As a result, the interior glass will be heated faster and its temperature is higher. As the flame is detached from the exterior pane, $T_{e}$ will not increase so fast as $T_{i}$ to give a positive $\Delta T$. Therefore, it is more likely that the interior pane will break first. Smoke or even flame can spread into the upper levels. 

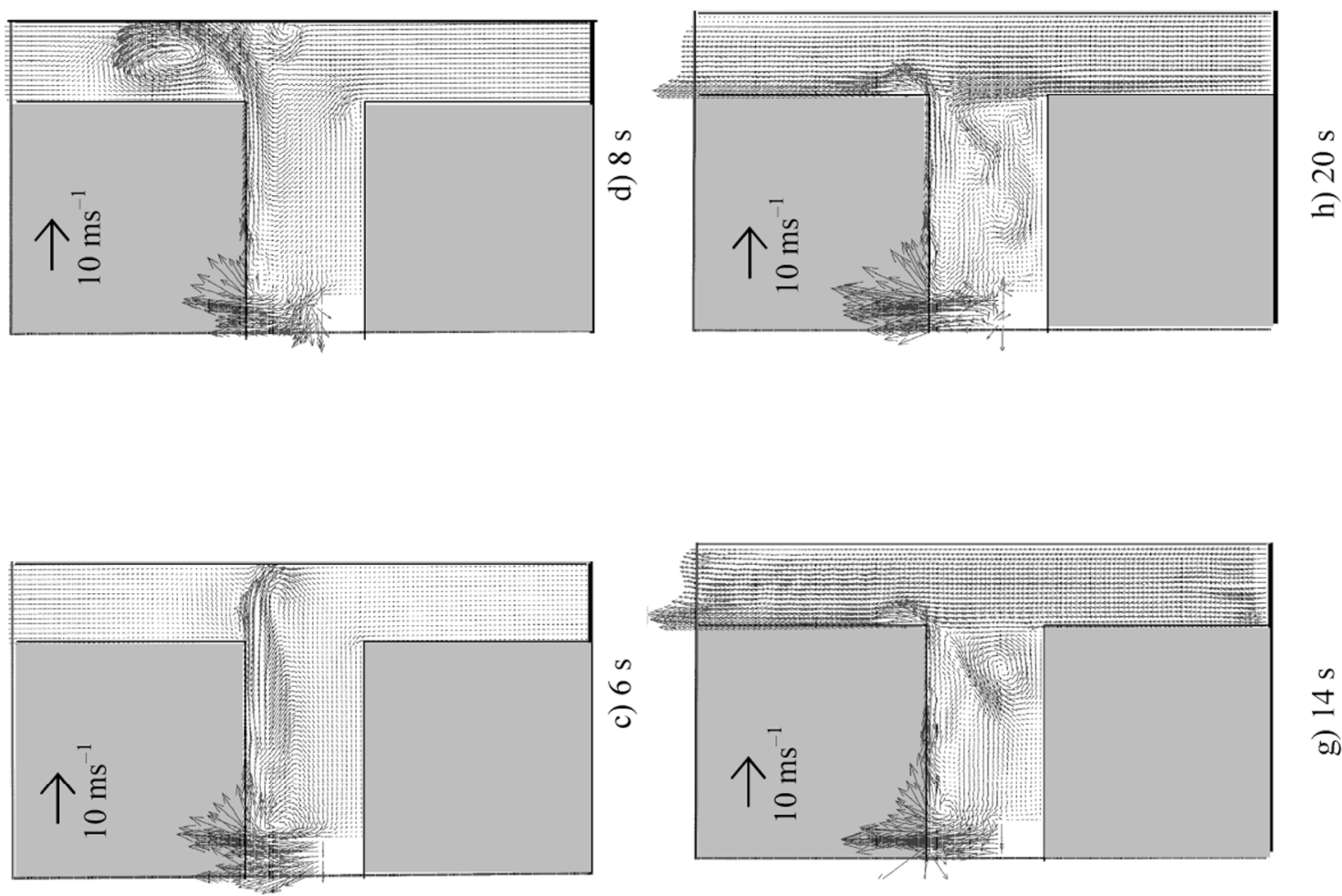

$\frac{ \pm}{20}$
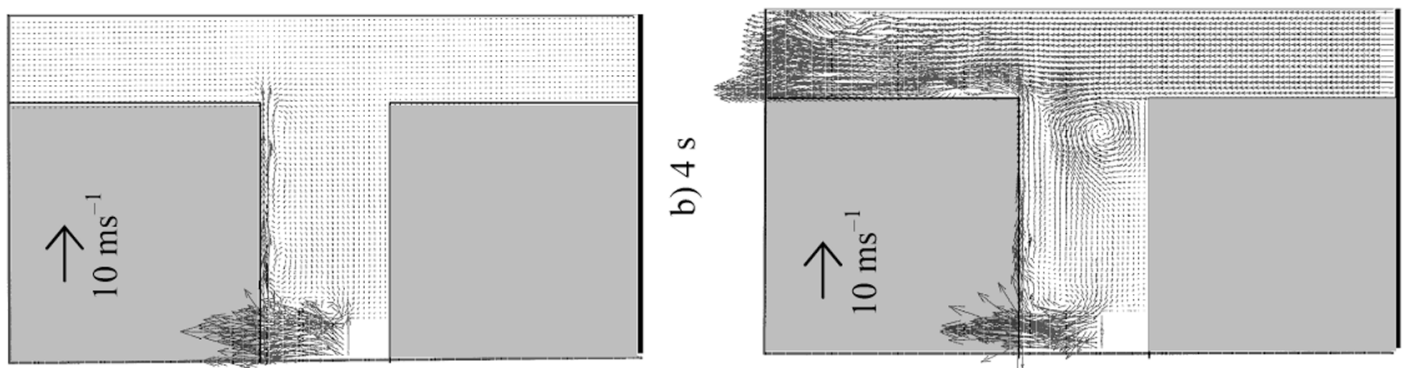

$\frac{n}{1}$

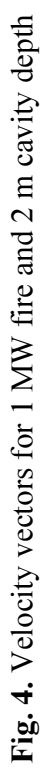



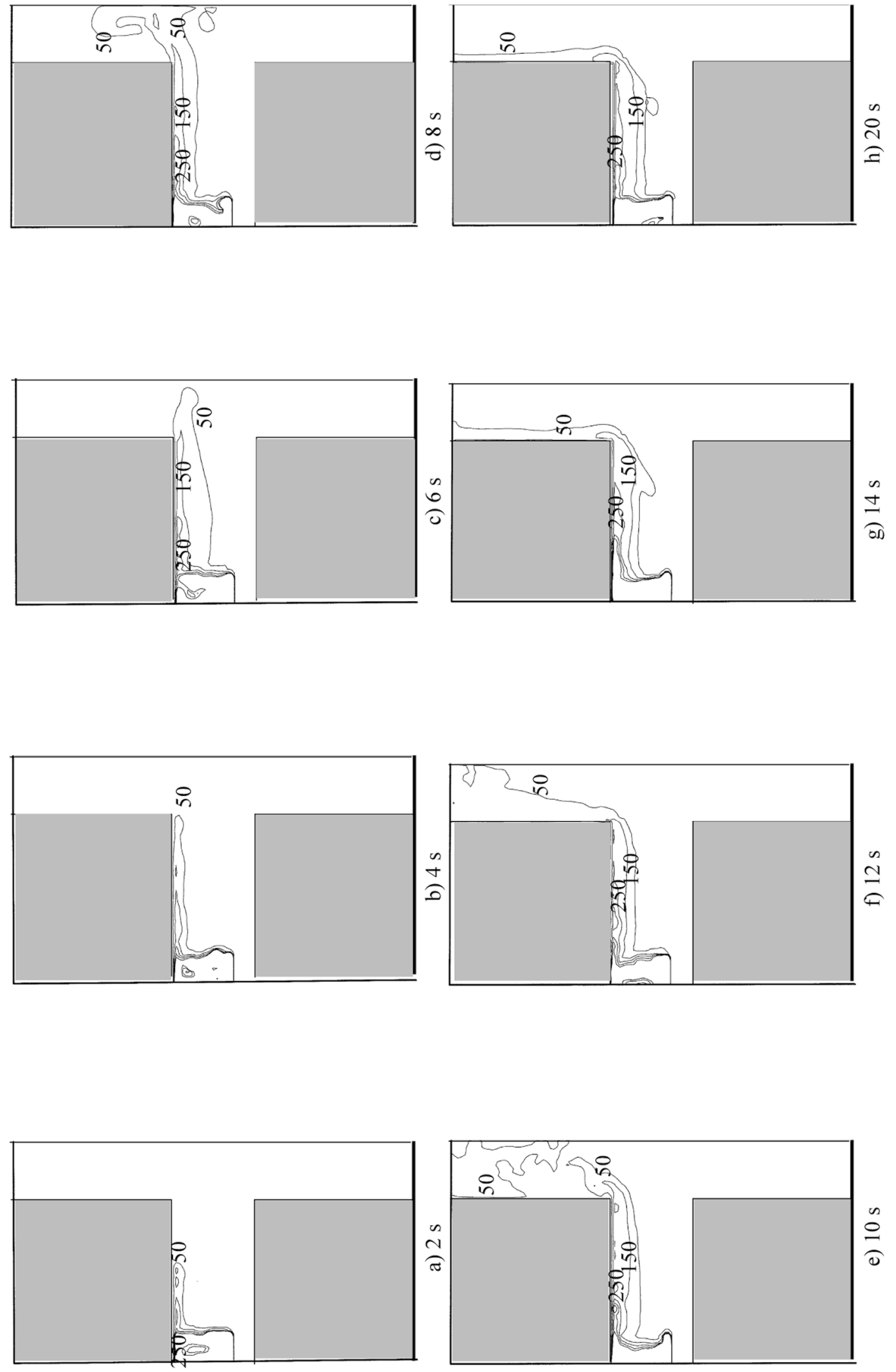

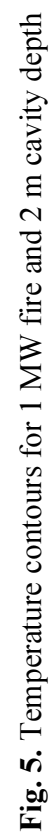



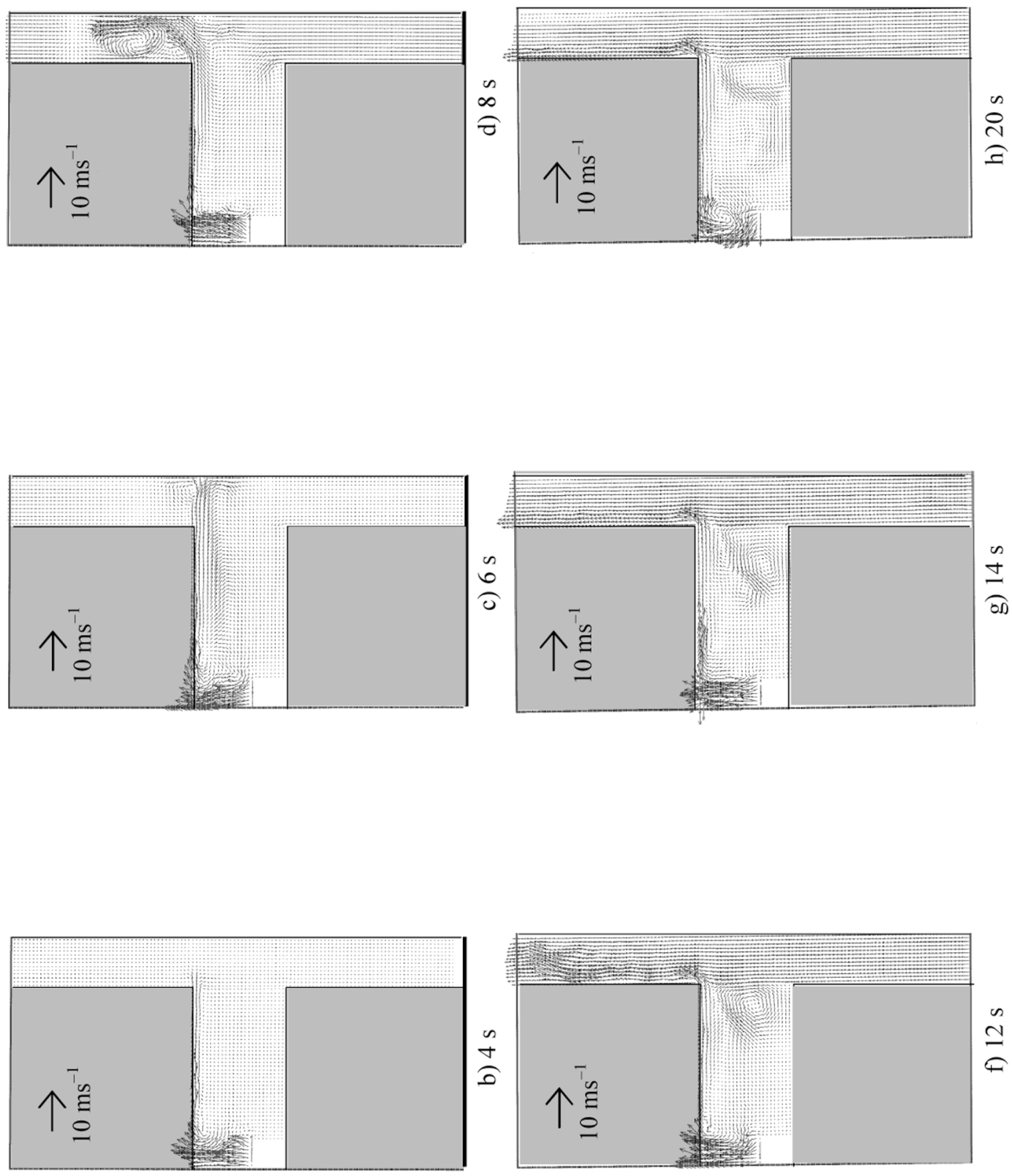

$\frac{n}{1}$
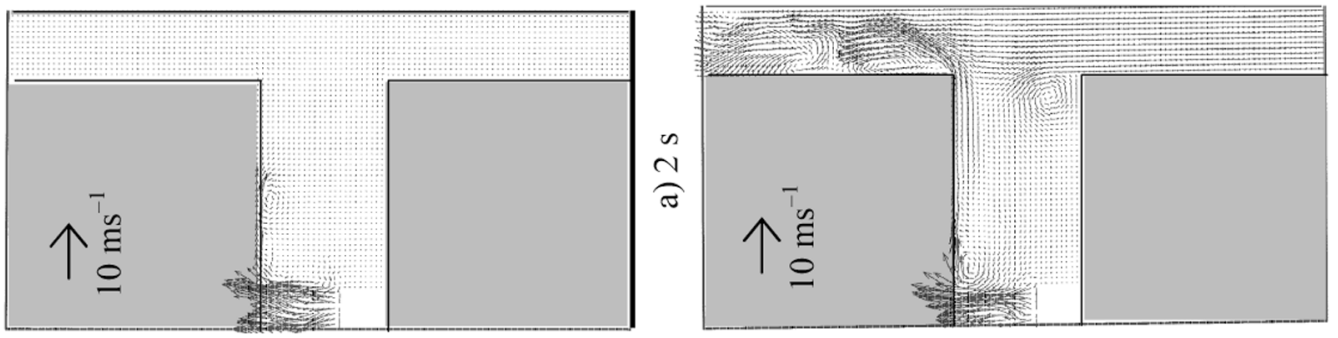

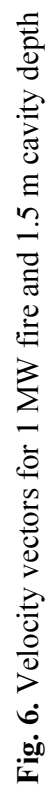



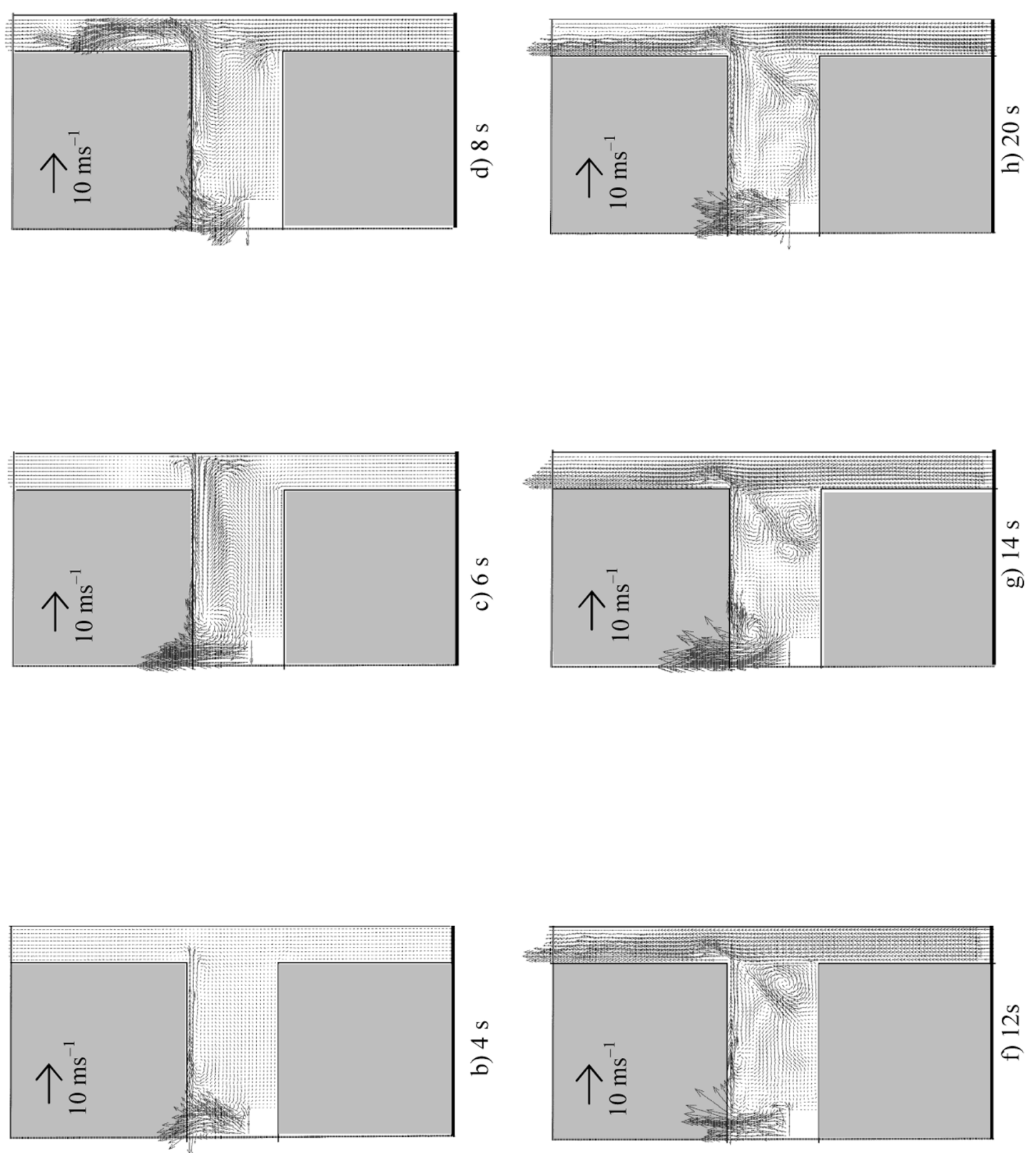

$\frac{\sqrt[3]{1}}{6}$

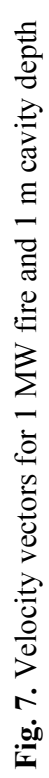



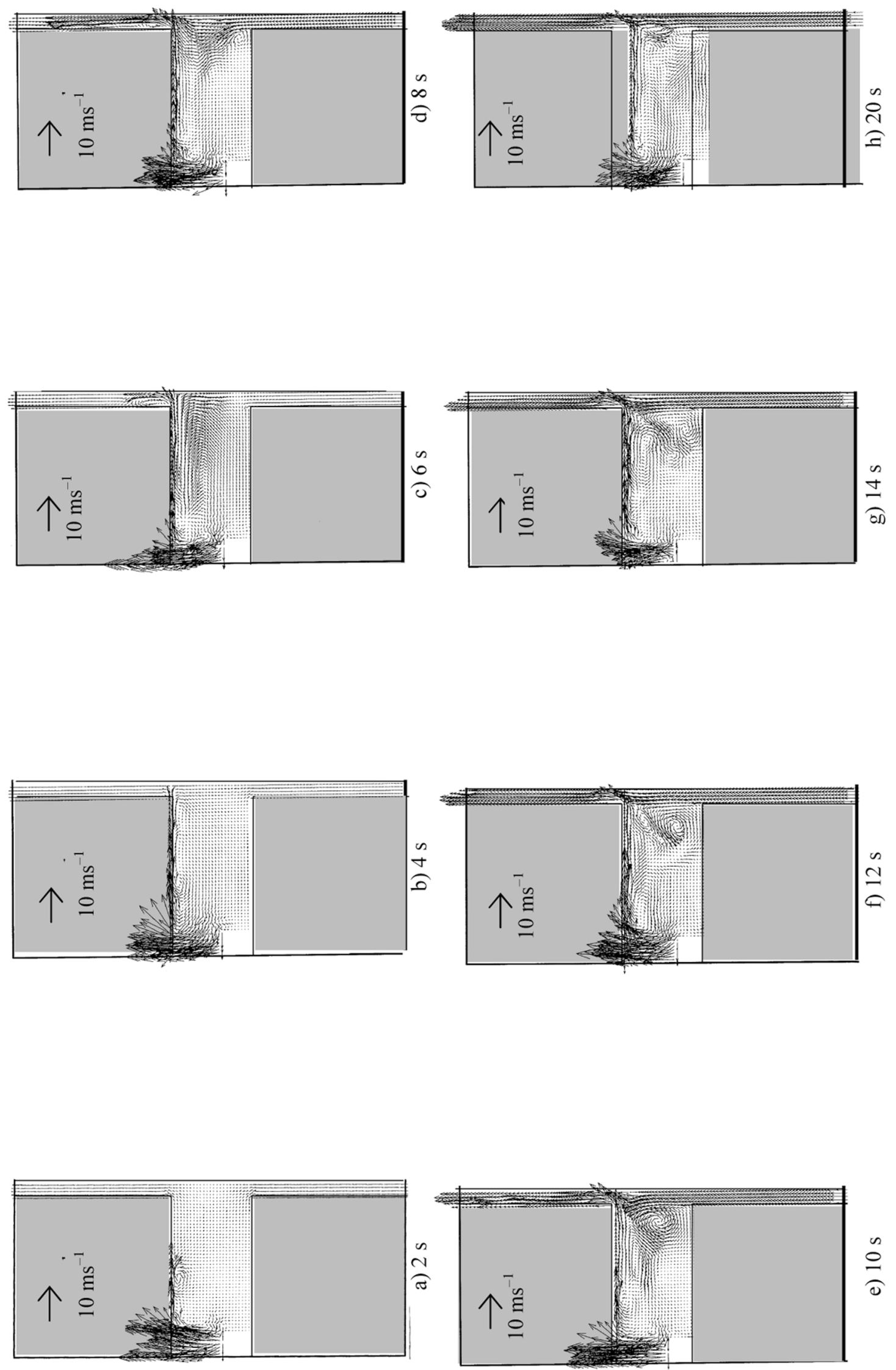

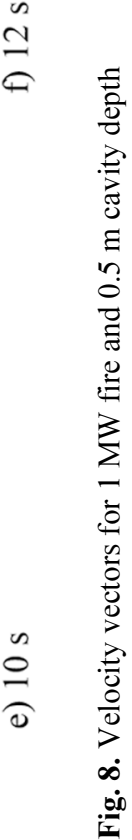




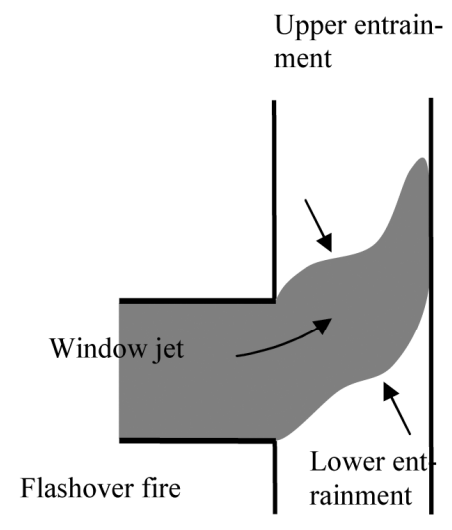

a) Initial

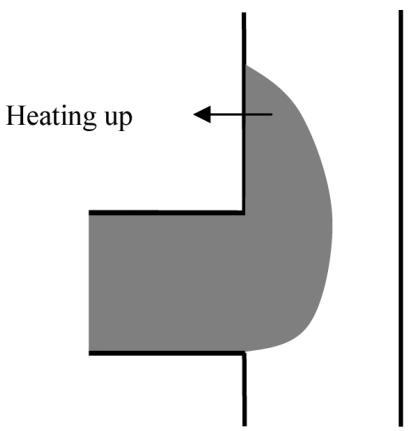

c) Adhered to the interior pane

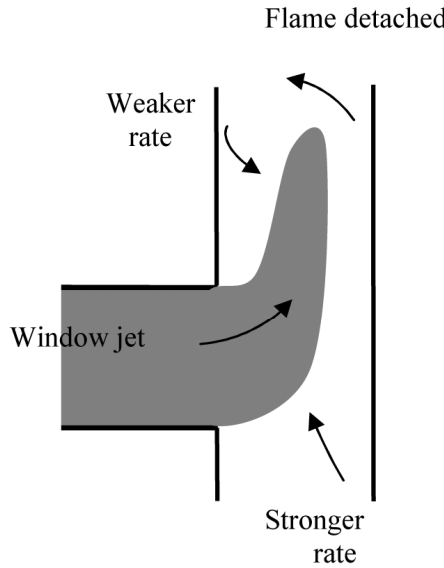

b) Detached from exterior pane

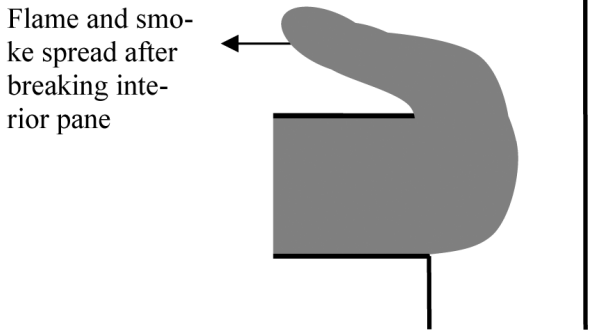

d) Spread to upper level

Fig. 9. Possible mechanisms on flame and smoke bending for wide air cavity

Thirdly, in the case in which the interior pane breaks first, the exterior pane might be broken if $T_{e}$ is heated to a high enough temperature, depending on the fire behaviour of the glass. If the exterior pane breaks later at time $t_{e}$, hot smoke and flame can still spread out when $t_{e}$ is shorter than the time of spreading into the upper level.

\section{Channel flow}

Hot air and flame would be ejected out of a compartment with a big fire when the glass pane is broken. Installing the exterior pane in a glass façade would limit the heat and mass spreading from that compartment to outside. To understand how air flow and heat transfer in the air cavity are affected, another two simulations were repeated by taking the exterior pane away with $1 \mathrm{MW}$ and $5 \mathrm{MW}$ fires. Results on the velocity vectors of the two fires are shown in Figs 10 and 11.

As observed from those velocity vectors, hot air is ejected out of the compartment with horizontal momentum due to ceiling jet. The horizontal momentum of air flow reduced while moving further away from the fire source, and entraining more surrounding air. The hot air motion changed direction and moved vertically due to buoyancy. The air entrainment rate from outside was stronger than that from the wall side. The hot air motion bent towards the upper façade and attached to the wall. This phenomenon is consistent with those reported recently (Himoto et al. 2009a, b). Vertical air temperature profiles for the $1 \mathrm{MW}$ and $5 \mathrm{MW}$ fires predicted at a computing cell of distance $0.125 \mathrm{~m}$ from the glass façade on all the above simulations are plotted in Fig. 14 to study the effect of putting in the exterior pane. The choice of $0.125 \mathrm{~m}$ is reasonably close to the interior pane for justifying the variation of the mean air temperature along the vertical height of the façade cavity. This distance is less than the boundary layer thickness estimated to be about $0.6 \mathrm{~m}$ as shown later. It is close enough to the interior pane in assessing the air temperature adjacent to the pane.

As a result of the velocity vectors patterns, hot air induced by the compartment fire moved out as a radial plume, or ceiling jet with high horizontal momentum. Outside air entrained would cool the ceiling jet down. Directions of the flow momentum changed and tilted towards the vertical direction as a plume. More air entrained to cool the plume, but still coming from all sides of the plume. Eventually, air entrainment from the wall side is smaller. The effect of entraining air from the two sides is no more symmetric. The plume then adhered to the wall as an attached flow. All the CFD predictions are consistent with what was observed experimentally by Himoto et al. (2009a, 2009b) on single-skin façade. 

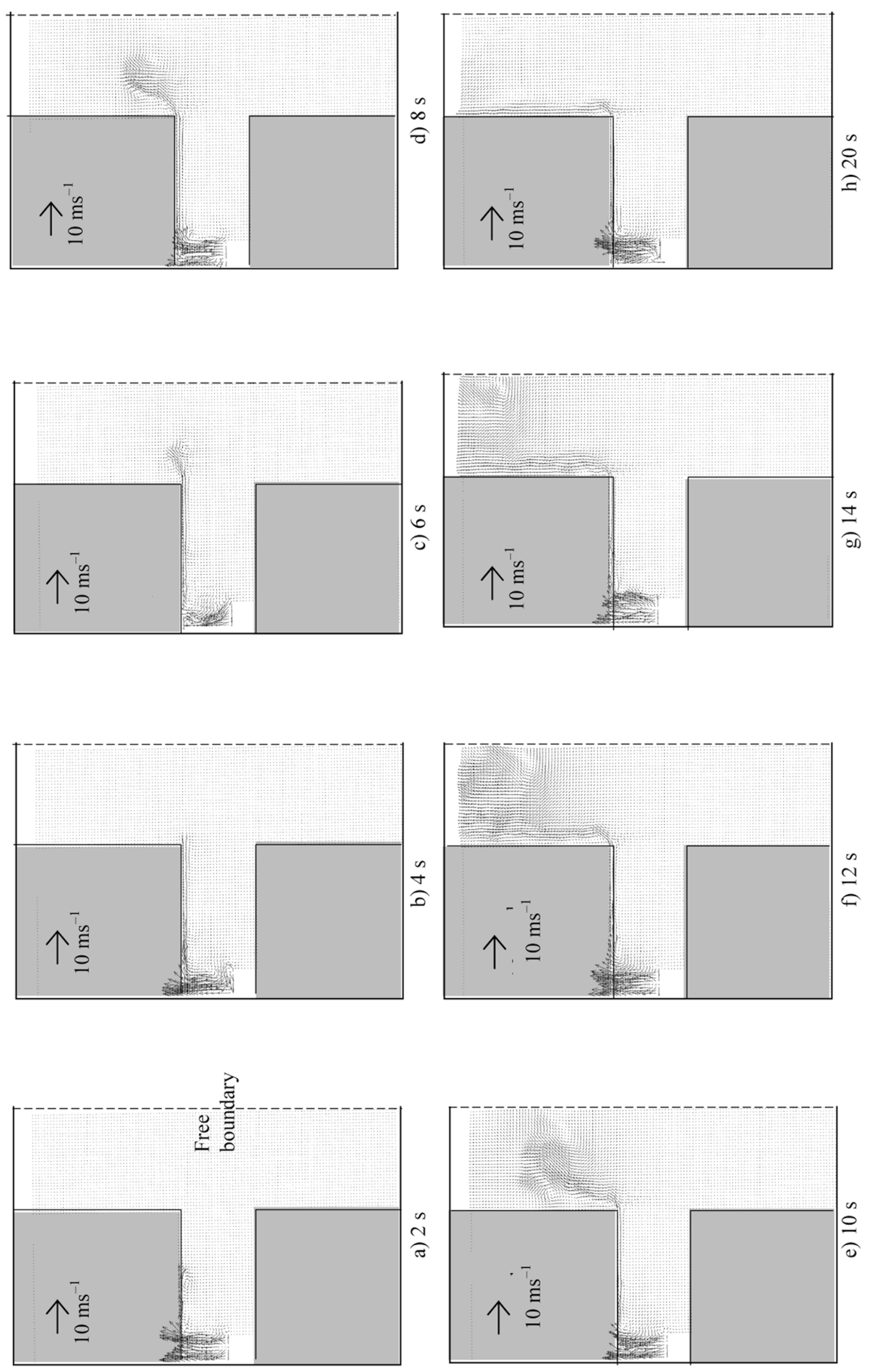

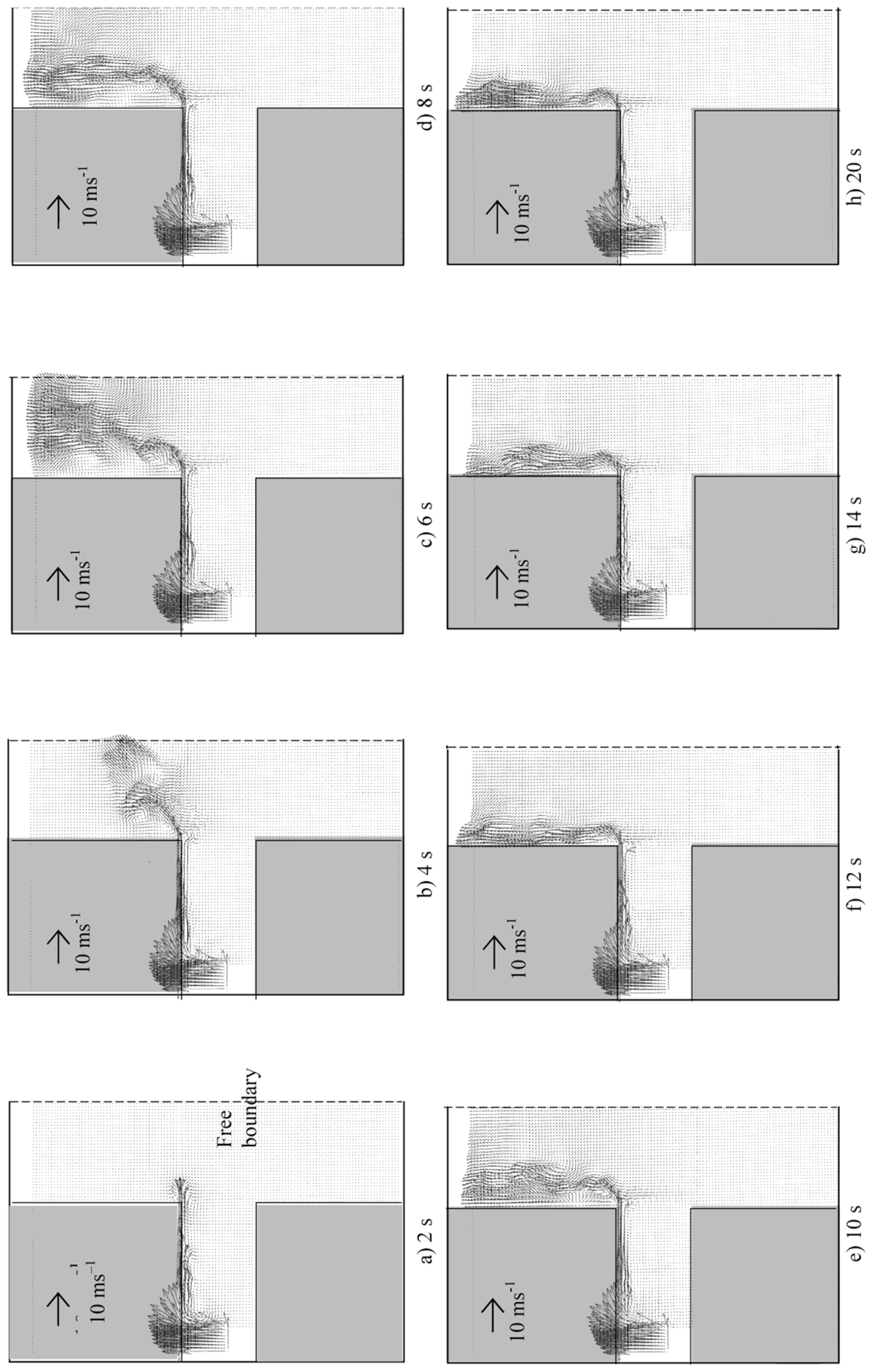

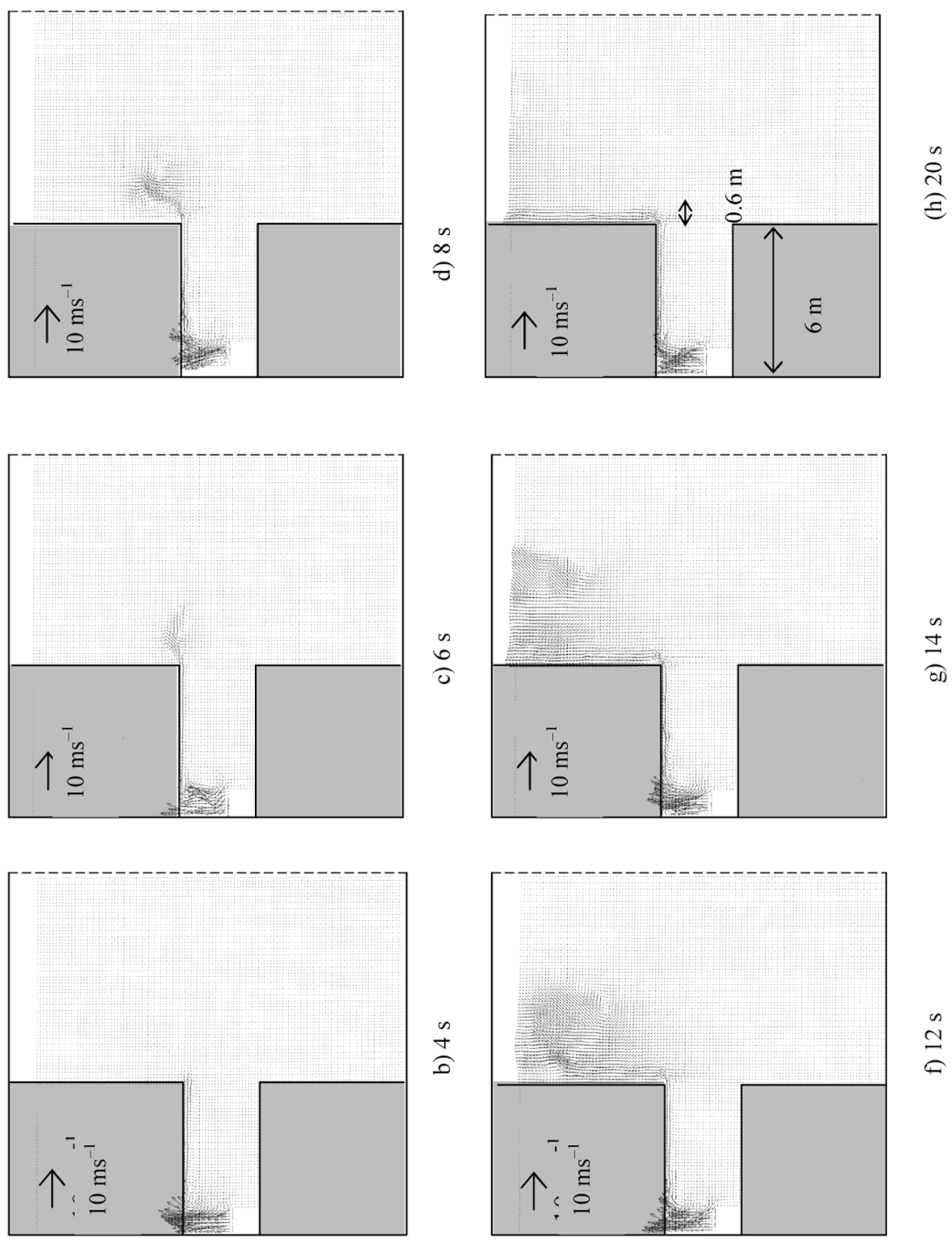

$\stackrel{n}{ \pm}$
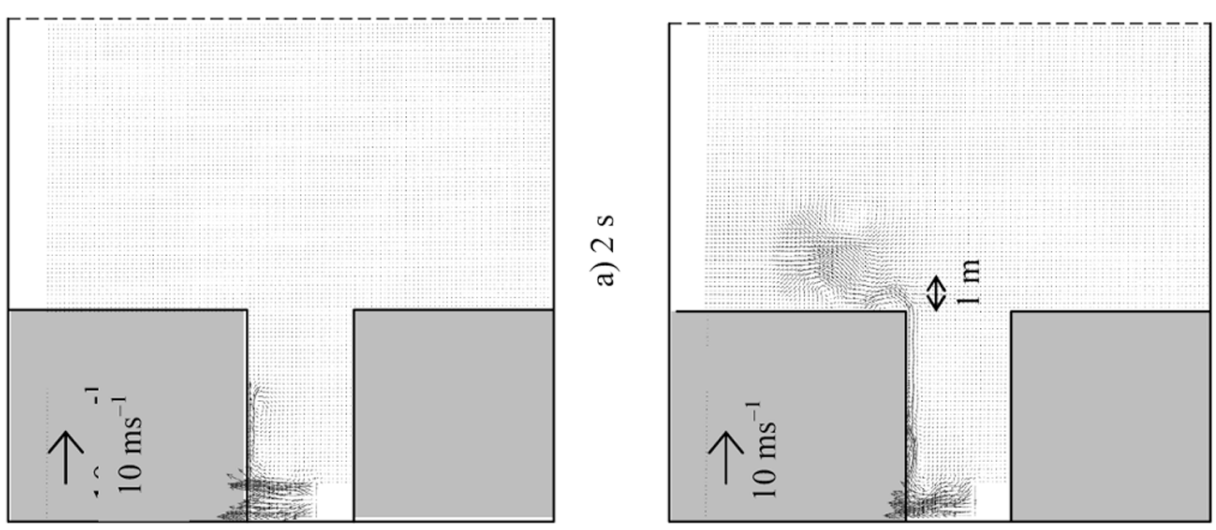

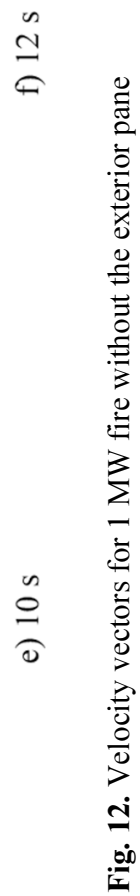



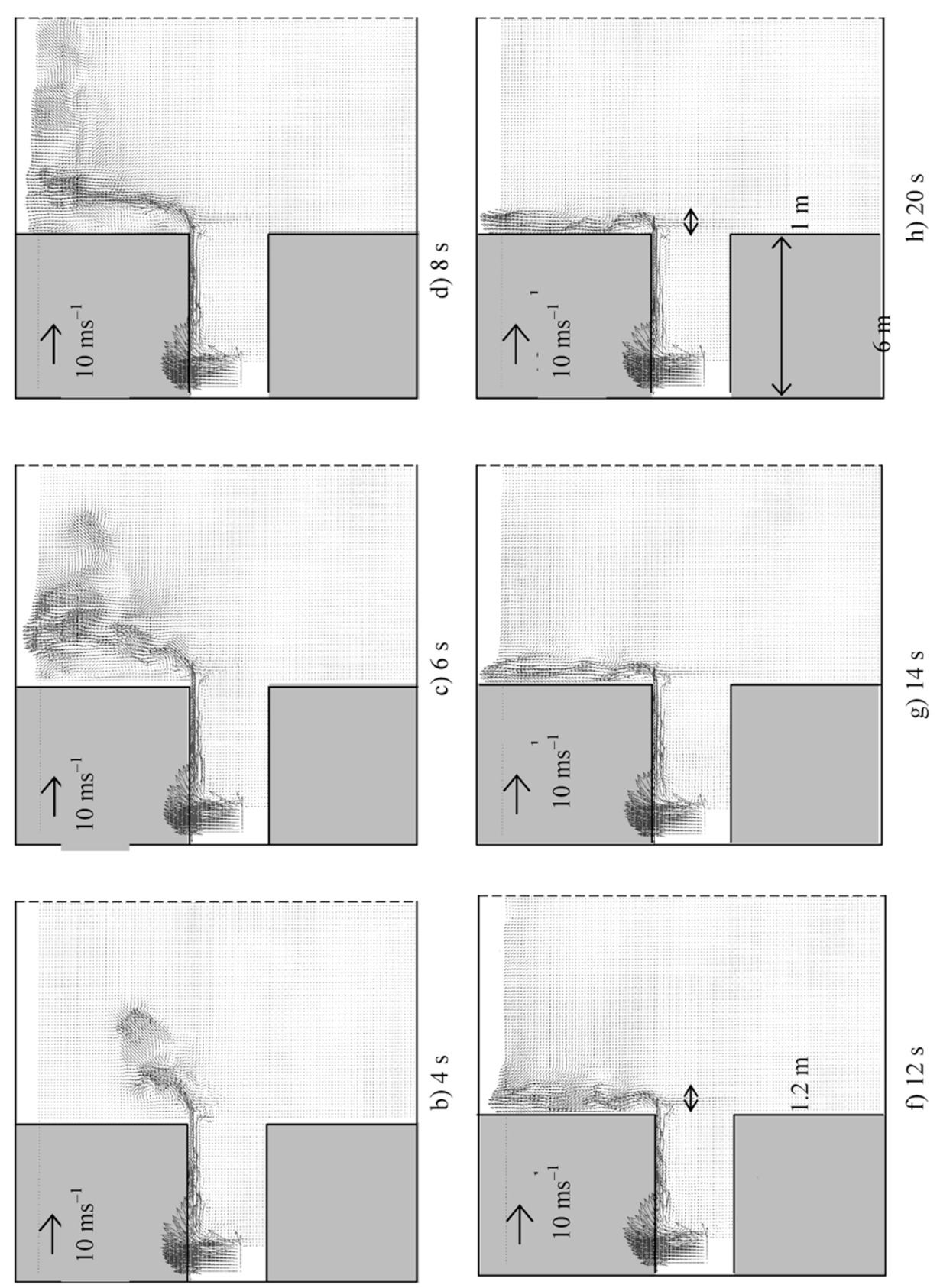

$\frac{\infty}{2}$
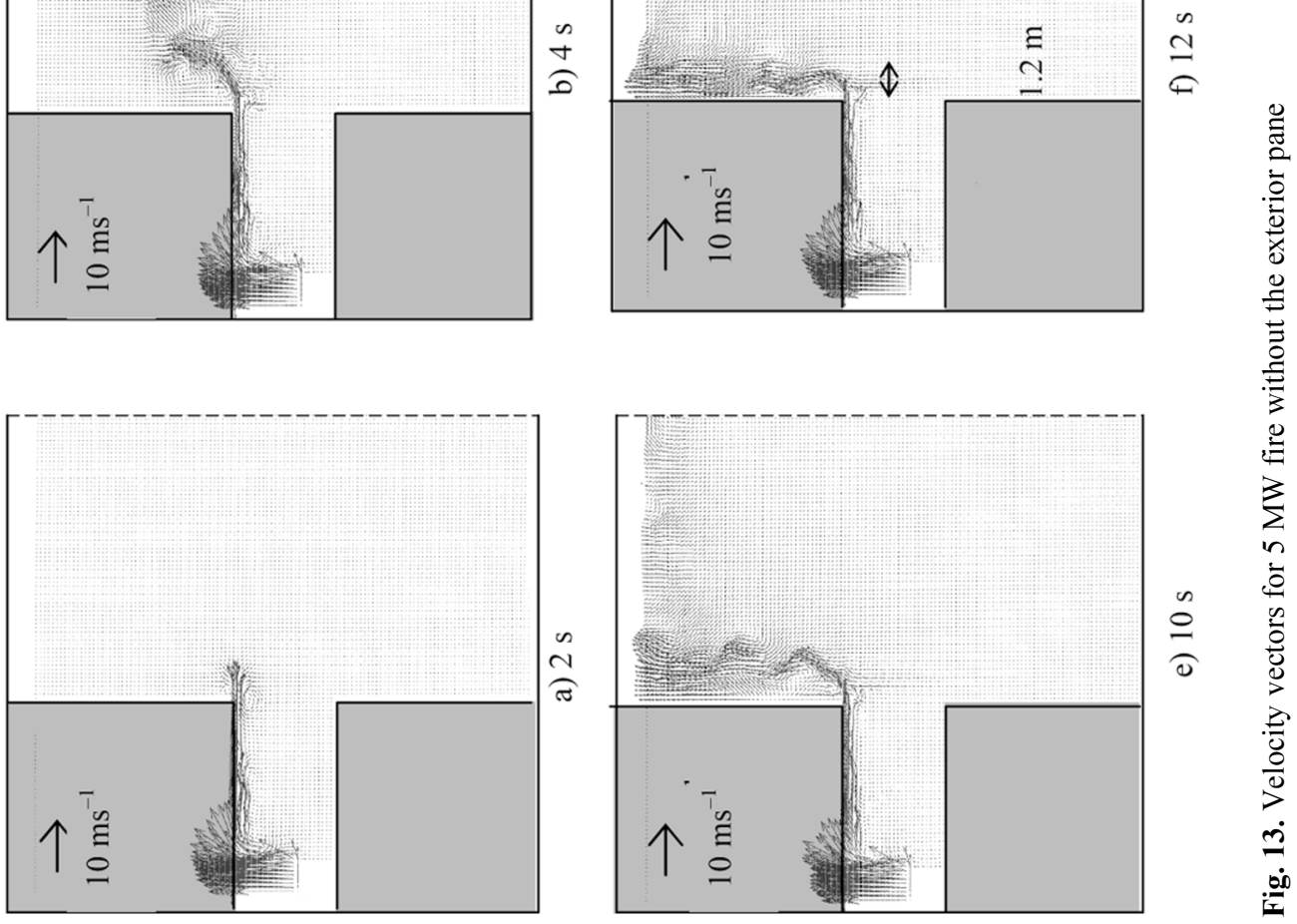
Results are different from the flow pattern of DSF as shown in Fig. 4 and Figs $6-8$ with differing cavity depths. The horizontal ceiling jet struck at the exterior panel and then formed another plume or "wall jet". Entrainment is more complicated, depending on cavity depth. Results with a wider air cavity depth of $2 \mathrm{~m}$ have similar air entrainment from both sides as in the case for singleskin façade without the exterior pane, with the plume adhering to the interior pane. But for a narrower cavity depth of $0.5 \mathrm{~m}$, hot air flowed up as a channel flow. Air temperature is high in the cavity though there are slight differences between the two panes.

In view of velocity vectors shown in Figs 10 to 11, it may be concluded that extending the domain out only by $4 \mathrm{~m}$ cannot accommodate the long 'throw' of ceiling jet induced by the fire. For a $1 \mathrm{MW}$ fire, predicted velocity vectors at $8 \mathrm{~s}$ and $12 \mathrm{~s}$ in Fig. 10f and g were restricted by the short free boundary at $4 \mathrm{~m}$. Results predicted by FDS at and after $10 \mathrm{~s}$ are therefore not correct, as the free boundary was not sufficiently long extended out of the façade. The problem is more serious for a $5 \mathrm{MW}$ fire because the window jet of higher momentum would move further outward. In view of results shown in Figs $11 \mathrm{~b}$ and c, the predicted velocity vectors at $4 \mathrm{~s}$ and $6 \mathrm{~s}$ were restricted by the short range of free boundary out of the façade.

Simulations were therefore repeated by extending the free boundary by $20 \mathrm{~m}$ as proposed (Schaelin et al. 1994; Mawhinney et al. 1994; Chow and Chow 2009b), but keeping the grid size inside the façade feature the same. Predicted velocity vectors by FDS are shown in Figs 12 and 13. It is observed that the long throw of horizontal motion can now be captured for both fire sizes. The range for hot

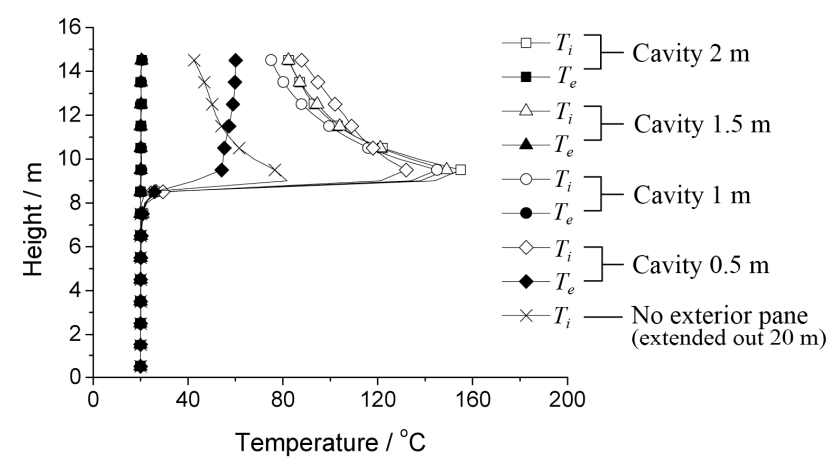

a) $1 \mathrm{MW}$ fire

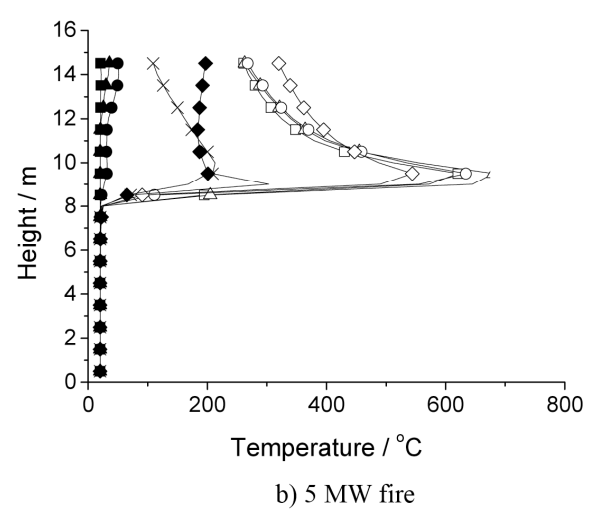

Fig. 14. Vertical temperature profiles for DSF1 gas motion induced by a $5 \mathrm{MW}$ fire is much longer, as shown in Fig. 13d, Fig. 12f for a $1 \mathrm{MW}$ fire.

Vertical air temperature profiles at the steady burning state next to the interior and exterior panes for the four air cavity depths are also plotted in Fig. 14 for $1 \mathrm{MW}$ and $5 \mathrm{MW}$ fires respectively. Results for the case without the exterior pane and two side walls, i.e. a single-skin façade, are also plotted. It is observed that air temperature above the fire room in the case without the exterior pane and side edges is reduced quickly at higher positions. This is a good indication that the vertical channel flow of hot air moved up from the DSF with a narrow cavity depth. It is particularly obvious in the case of $0.5 \mathrm{~m}$ cavity depth. For air cavity depths of $1 \mathrm{~m}, 1.5 \mathrm{~m}$ and $2 \mathrm{~m}$, the air temperatures next to the exterior and interior panes were markedly different at the steady burning state. Taking cavity depth of $2 \mathrm{~m}$ as an example, air temperature next to the interior pane can be up to $600{ }^{\circ} \mathrm{C}$ for DSF1 with a $5 \mathrm{MW}$ fire. However, air temperature next to the exterior pane was low.

\section{Simulations with a taller rig}

The DSF feature in the above CFD simulations is good for understanding how the induced flow pattern of the ejected window flame is affected by the exterior pane by capturing pictures. However, it is not tall enough to allow study of channel flow. Additional simulations were studied in two taller DSF features DSF2 and DSF3 as in Fig. 15. As in the above geometry DSF1, the fire started at a level $6 \mathrm{~m}$ above the ground in both DSF2 and DSF3. This would include the air entrainment effect from below. In DSF2, the fire compartment was taller of height $6 \mathrm{~m}$. The vertical façade was extended to $12 \mathrm{~m}$. For DSF3, the room geometry was same as for DSF1, but the façade height extended to $15 \mathrm{~m}$. Both DSF2 and DSF3 were divided into up to 80,40 and 192 parts in the $\mathrm{x}, \mathrm{y}$ and $\mathrm{z}$ directions. Computing details are similar to those for DSF1.

Results on vertical air temperature profiles next to the interior and exterior panes on the two features DSF2 and DSF3 are shown from Figs 16 and 17 for $1 \mathrm{MW}$ and $5 \mathrm{MW}$ fire respectively. Air temperatures next to the interior panes at the upper level for DSF were higher than those for single-skin façade without the exterior pane and two edges.

For narrow cavity depth of $0.5 \mathrm{~m}$ with a $5 \mathrm{MW}$ fire in the room, air temperatures next to the interior and exterior panes are both at high values above $200{ }^{\circ} \mathrm{C}$. Note that much lower air temperatures at less than $50^{\circ} \mathrm{C}$ were predicted for single-skin façade, as shown in Figs 16 and 17 as heat is lost to the outside ambient. This is very dangerous for such a hot air cavity because interior glass panes at the upper level can be broken easily. Hot gases would then spread into the upper room and ignite all combustibles to produce another big room fire. The process can be repeated to spread up to rooms near to the glass DSF. This jumping up scenario was demonstrated in the experiments on part of a full-scale DSF.

From the simulations with DSF1 to DSF3, it is further confirmed that fire-induced aerodynamics in the air 


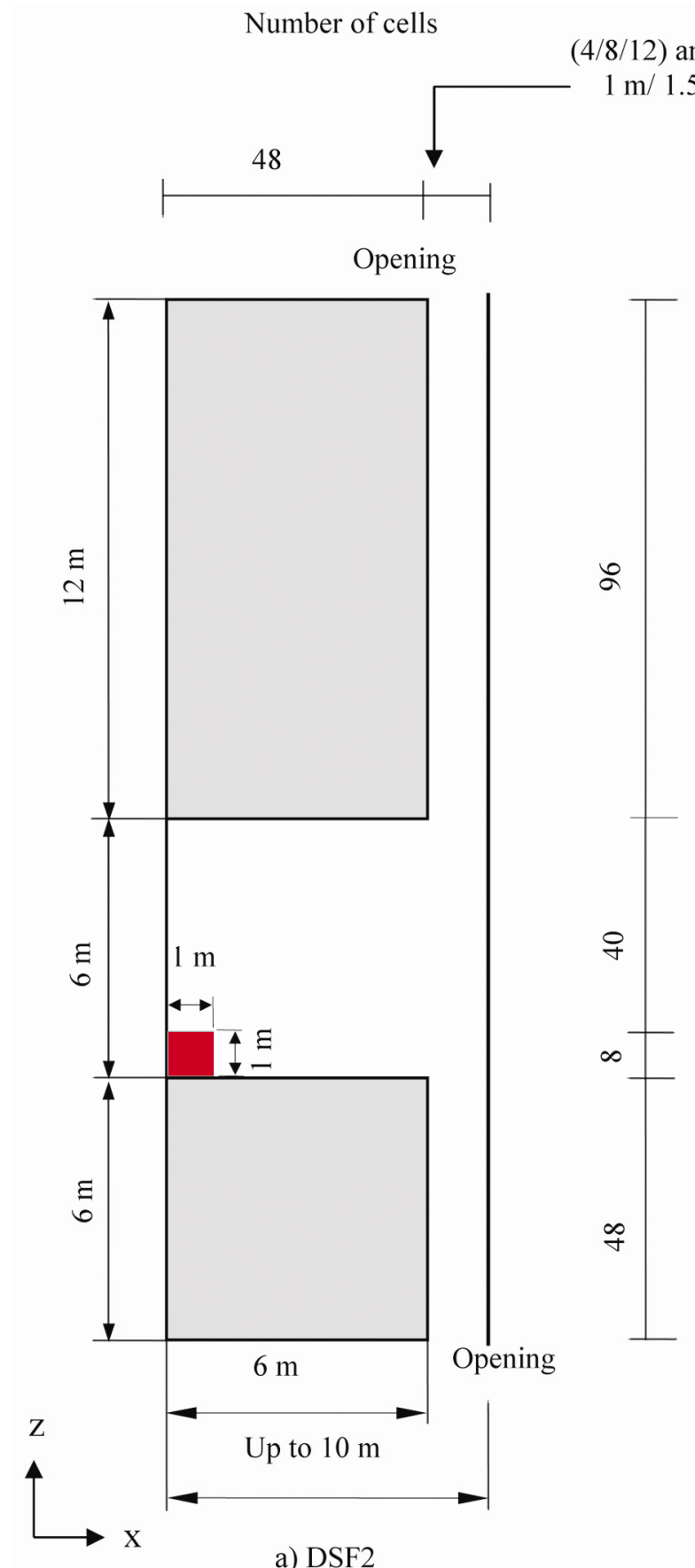

Number of cells

/8/12) and (28/24/20) for $0.5 \mathrm{~m} /$
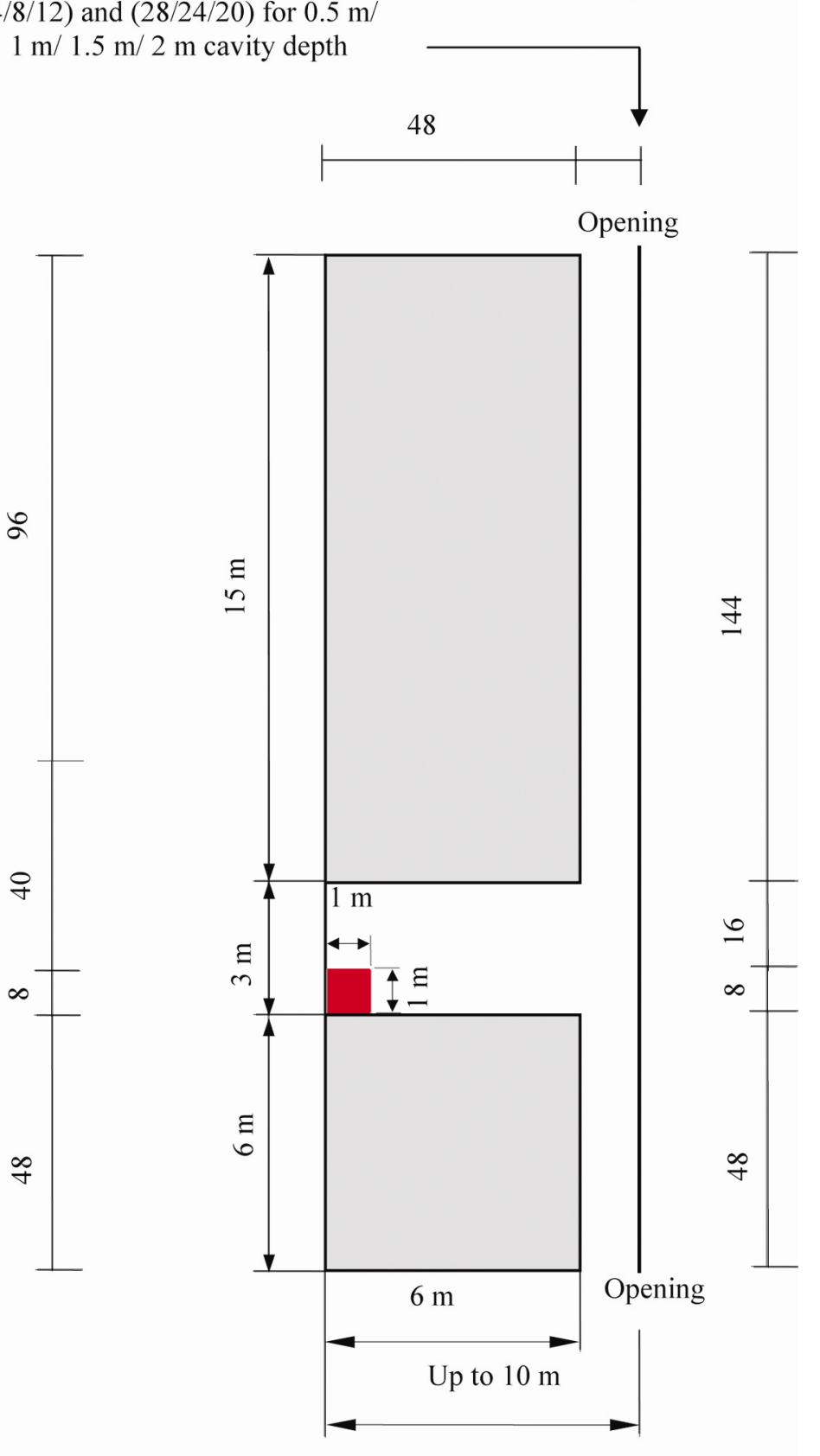

a) DSF2

b) DSF3

Fig. 15. Elevations of DSF2 and DSF3

cavity may be described as a vertical hot channel flow: fire can spread upward easily as the air temperatures in the cavity are much hotter than those for single-skin façade as shown in Figs 14, 16 and 17 for the three DSF features.

\section{Analysis of grid systems}

There are computer hardware limitations in getting a powerful processor for performing the simulations. The main computer system available for early study was a personal computer with $1 \mathrm{~GB}$ random access memory
(RAM) and 80 GB hard disk. The central processing unit (CPU) is of speed $2.8 \mathrm{GHz}$. The maximum number of cells can be handled in this computer system is about 1 million. The computing time required for such a fine grid system was very long. The key objective on CFD simulations carried out in this paper is to understand the possible physical phenomena on heat and mass trapped in the façade cavity due to an adjacent room fire, and then verify the results by experimental studies. Therefore, the grid system with up to 384,000 cells, divided into 80 by 40 by 120 parts along the $x-, y-$ and $z$-directions was selected in the simulations with DSF1. 


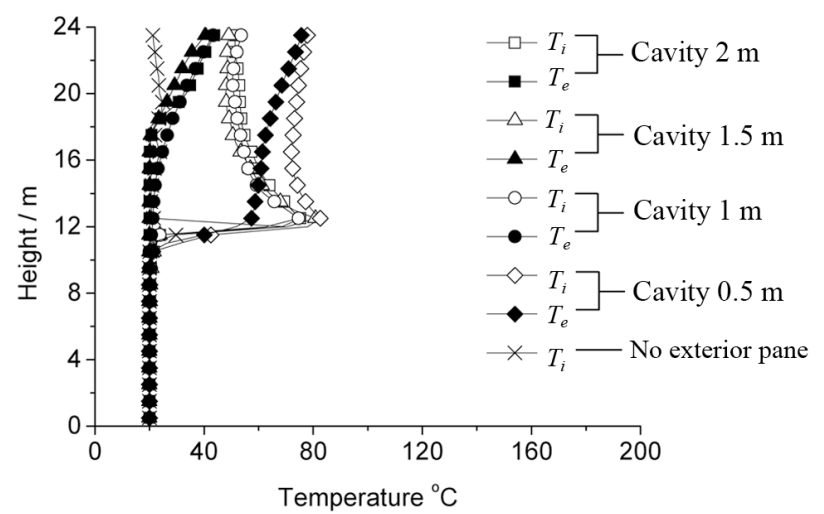

a) $1 \mathrm{MW}$ fire

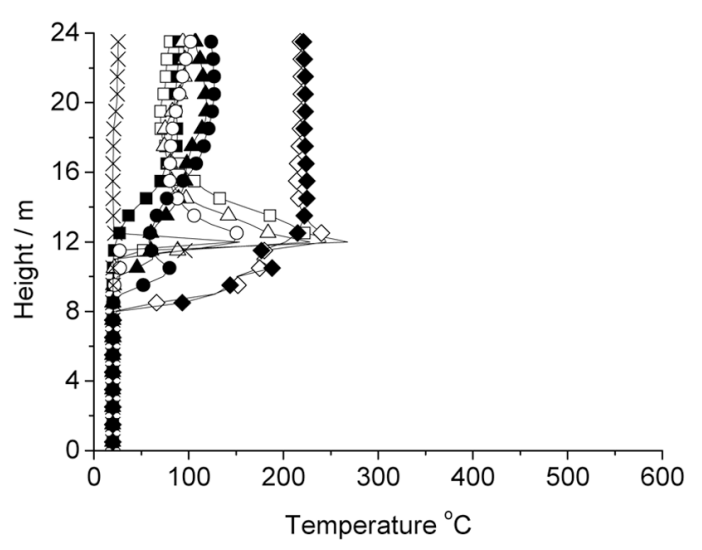

b) $5 \mathrm{MW}$ fire

Fig. 16. Vertical temperature profiles for DSF2

However, it is still essential to understand how the predicted results varied with the grid size. The set of DSF 1 simulations under a $1 \mathrm{MW}$ fire with $2 \mathrm{~m}$ cavity depth was selected to study the effect of varying grid sizes. Grid systems coarser and finer than the selected one of 384,000 cells were tested to observe how the flame spread out from the room and was trapped in the façade cavity. A more powerful computer was used for the number crunching exercises in simulations with fine grids. This new computing system has 2 processors at speed $3.16 \mathrm{GHz}, 4 \mathrm{~GB}$ RAM and $320 \mathrm{~GB}$ hard disk. The CPU has new computer architecture and cases with finer grid sizes up to 3 million cells can be simulated.

The following fine grid systems are tested:

- DSF1f1: Double the number of grid sizes along the $\mathrm{x}$ - and $\mathrm{z}$-directions on the above to give $1,536,000$ cells, divided into 160 by 40 by 240 parts along the three directions. This is four times the grid system selected for the simulations carried out above.

- DSF1f2: 1.5 times the number of grid sizes along the $\mathrm{x}-, \mathrm{y}-$ and $\mathrm{z}$-directions as in above to give $1,296,000$ cells, divided into 120 by 60 by 180 parts along the three directions. This is 3.375 times the grid system selected.

- DSF1f3: Double the number of grid sizes along the $\mathrm{x}-, \mathrm{y}-$ and $\mathrm{z}$-directions to give $3,072,000$ cells, divided into 160 by 80 by 240 parts along the three directions. This is eight times the grid system selected.

On the above finer grid systems, only DSF1f2 with $1,296,000$ cells can be executed in the old pentium system. Therefore, the old computing system can only handle up to about 1.2 million cells. On the new pentium system, up to 3 million cells can be handled. Error message 'memory allocation failed' reported in the more powerful system while handling simulations with $3,840,000$ cells or 10 times the number of cells of the selected grid system.

In addition, two more coarser grid systems are tested on DSF1:

- DSF1c1: Half the number of grid sizes of the selected system along all the $\mathrm{x}-, \mathrm{y}$ - and $\mathrm{z}$-directions to give up to 48,000 cells, divided into 40 by 20 by 60 parts along the three directions.

- DSF1c1: 0.8 times the number of grid sizes of the selected system along the $\mathrm{x}-, \mathrm{y}$ - and z-directions to give up to 196,608 cells, divided into 64 by 32 by 96 parts along the three directions.

The predicted flow patterns and temperature contours for the above fine and coarse grid systems in DSF1 simulation with $2 \mathrm{~m}$ cavity depth and $1 \mathrm{MW}$ fire are similar as reported in Chow (2009). Therefore, heat and mass spread processes simulated by the above grid system of 384,000 cells are adequate to understand the potential fire hazard.

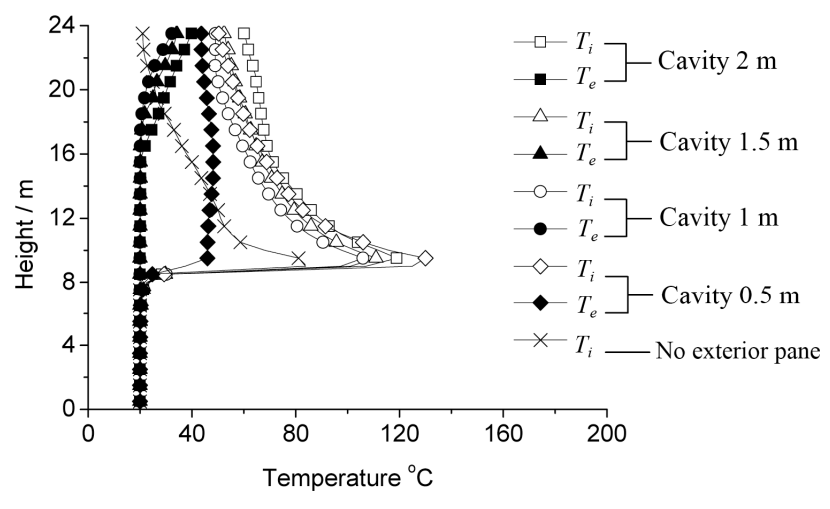

a) $1 \mathrm{MW}$ fire

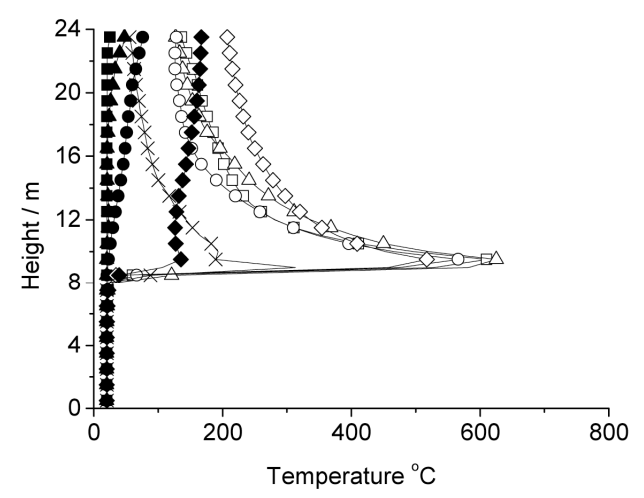

b) 5 MW fire

Fig. 17. Vertical temperature profiles for DSF3 
Sensitivity of grid size on CFD predicted results depends on the nature of the problem itself. There is no sensitivity study on smoke movement in tall buildings as in this paper. Some results reported earlier on closed pressure chamber and atrium hot smoke tests (Chow and Zou 2009; Chow et al. 2009) indicated that grid size similar to this study would be adequate to understand the fireinduced flow pattern and air temperature contours.

There were sensitivity studies (Ma and Quintiere 2003) with grid size on estimating flame length and physical properties of a thermal plume induced by a pool fire using earlier version of FDS (i.e. FDS 2.0). A characteristic plume length scale $z^{*}$ is defined in terms of the effective diameter $D_{e}$ (diameter of the circle with equivalent fuel area) and the dimensionless fire power $Q_{D}{ }^{*}$ as:

$$
z^{*}=\left(Q_{D}{ }^{*}\right)^{2 / 5} D_{e},
$$

where $Q_{D}{ }^{*}$ is related to heat release rate of the fire $Q$ (in $\mathrm{kW})$, specific heat capacity of air $\left(1 \mathrm{Jg}^{-1} \mathrm{~K}^{-1}\right)$, ambient temperature $T_{\infty}$ and ambient density $\rho_{\infty}$ as:

$$
Q_{D}^{*}=Q /\left(\rho_{\infty} C_{p} T_{\infty} \sqrt{g D_{e}} \cdot D_{e}^{2}\right) .
$$

A dimensionless number $R^{*}$ on describing resolution of the grid system is defined in terms of the maximum grid size $\Delta x, \Delta y$ and $\Delta z$ along the three directions $x, y$ and $z$ :

$$
R^{*}=\operatorname{Max}(\Delta x, \Delta y, \Delta z) / z^{*} .
$$

Optimum resolution is found when $R^{*}$ is smaller than 0.1 . The value should be down to 0.05 for studying flame length induced by a pool fire.

Again, taking DSF 1 with $2 \mathrm{~m}$ cavity depth in above with $Q$ of $1 \mathrm{MW}, Q_{D}{ }^{*}$ is 2.75 for $T_{\infty}$ at $298 \mathrm{~K}$. The fuel area $1 \mathrm{~m}$ by $1 \mathrm{~m}$ gives $D_{e}$ of $0.683 \mathrm{~m}$. The value of $z^{*}$ is then $1.02 . R^{*}$ is 0.15 for the grid system selected of 384,000 cells ( 80 by 40 by 120 ) with $\operatorname{Max}(\Delta x, \Delta y, \Delta z)$ of $0.15 \mathrm{~m}$.

The selected grid size due to hardware limitation would not give fine resolution as proposed (Ma and Quintiere 2003) on predicting accurately flame length and physical properties of thermal plumes induced by a pool fire using FDS 2.0. However, such coarse grid system would give reasonable predictions on flow pattern and shapes of temperature contours in the façade cavity as demonstrated (Chow 2009).

On the $1 \mathrm{MW}$ fire simulation with the finer grid system DSF1f2 with $1,296,000$ cells, $\operatorname{Max}(\Delta x, \Delta y, \Delta z)$ is reduced to $0.1 \mathrm{~m}$. The value of $R^{*}$ is now 0.1 and so fine enough to give reasonable predictions even on flame length and physical properties of a thermal plume induced by a pool fire as proposed (Chow et al. 2009). On the finest grid system DSF1f3 with $3,072,000$ cells, $R^{*}$ is reduced to 0.075 .

Value of $z^{*}$ would be $1.94 \mathrm{~m}$ for the $5 \mathrm{MW}$ fire simulation on DSF1. This gives a high value of $Q_{D}{ }^{*}$ of 13.75 . The same coarse grid system of 384,000 cells ( 80 by 40 by 120 ) gives a lower $R^{*}$ of 0.08 , satisfying condition of $R^{*}$ lower than 0.1 .
However, such grid sensitivity is not critical as the objective of this CFD study is to understand the flow pattern and temperature contours inside the DSF cavity. The physical phenomenon would be justified by experimental studies. All these demonstrated that the grid system selected in the above simulations is good enough to study how heat and mass spreading out from a room fire are trapped in the façade cavity.

\section{Boundary layer thickness}

Numerous works are reported in the literature on predicting boundary layer thickness for convective heat transfer over a hot plate. Although very limited works are reported on application of FDS specifically, CFD predictions on both the momentum and thermal boundary layer thickness over a heated vertical or horizontal plate are acceptable. In fact, CFD was applied to study a window jet spreading out to a DSF cavity in this paper. No systematic verifications on CFD-FDS predictions on the associated air boundary layer have been reported yet. Numerical and experimental works on studying this problem in this paper are extensive but with resources limitations. There were difficulties in purchasing many fine thermocouples, hot-wire anemometers, thermal vision camera or PIV though such instruments are required to give good experimental data.

However, the works on modeling the trajectory of window flames (Himoto et al. 2009a, b) would give some indication of the boundary layer thickness associated with this problem. Based on simple mathematical analysis with scale model experiments, the following equation on separation distance between the attachment point and the wall $L_{E}$, which can be taken as an estimation of the boundary layer thickness of this specific problem, is given by :

$$
\frac{L_{E}}{B}=0.21 F^{*} \text {. }
$$

The parameter $F^{*}$ is given in terms of the horizontal velocity $u_{o}\left(\right.$ in $\left.\mathrm{ms}^{-1}\right)$ due to a fire of heat release rate $\dot{Q}$ (in $\mathrm{kW}$ ), window width $B$ (in $\mathrm{m}$ ), room height $H$ (in $\mathrm{m}$ ) and neutral plane height $z_{N}$ (in $\mathrm{m}$ ) as:

$$
F^{*}=\left(u_{o} / \sqrt{g B}\right)^{2}\left(\dot{Q} /\left(\rho_{\infty} C_{p} T_{\infty} g^{1 / 2} B\left(H-z_{N}\right)^{3 / 2}\right)^{-2 / 3}\right. \text {, }
$$

where $u_{\mathrm{o}}$ (in $\mathrm{ms}^{-1}$ ) can be estimated using the ceiling jet analysis (Alpert 2003). Using dimensionless ceiling jet velocity $u_{0}^{*}$ :

$$
u_{o}=u_{o}^{*} \sqrt{g H}\left(\dot{Q} / \rho_{\infty} C_{p} T_{\infty} g^{1 / 2} H^{5 / 2}\right)^{1 / 3} .
$$

A graph plotting $u_{0}{ }^{*}$ against normalized distance away from the fire $r / H$ with $r$ (in m) was compiled. Putting expression (9) with equation (8) and the values $H$ of $3 \mathrm{~m},\left(H-z_{N}\right)$ of $1.5 \mathrm{~m}$ and $T_{\infty}$ of $300 \mathrm{~K}$ to equation (7) gives:

$$
L_{E}=0.1 u_{\mathrm{o}}{ }^{* 2} B^{2 / 3} .
$$

For $r$ of $5.5 \mathrm{~m}$ or $1.83 \mathrm{H}$ as in the CFD-FDS such as the geometry in DSF1 as in Fig. 2 on removing the 
exterior pane, $u_{\mathrm{o}}{ }^{*}$ is about 1.2. Value of $L_{E}$ for B of $6 \mathrm{~m}$ as in the DSF1 simulation is about $0.7 \mathrm{~m}$.

In view of the CFD-FDS predictions on DSF1 in Figs 12 and 13 with free boundaries, $L_{E}$ is roughly of similar magnitude $0.6 \mathrm{~m}$ and $1 \mathrm{~m}$ for $1 \mathrm{MW}$ and $5 \mathrm{MW}$ fires respectively. This is a good indication that FDS agreed reasonably well with the expressions on boundary layer thickness reported (Himoto et al. 2009a,b).

\section{Conclusions}

Fire hazards of DSF are studied with CFD in this paper. A scenario of a flashover fire in a room adjacent to the DSF was identified earlier. Air flow driven by a room fire to the façade cavity was simulated. Four cavity depths of
$2 \mathrm{~m}, 1.5 \mathrm{~m}, 1 \mathrm{~m}$ and $0.5 \mathrm{~m}$ were studied under two fires of $1 \mathrm{MW}$ and $5 \mathrm{MW}$ with three DSF features DSF1, DSF2 and DSF3. Possible fire spread patterns in the façade cavity can be judged from the CFD predictions.

Results suggested that for a DSF with wider aircavity depth of $2 \mathrm{~m}$, there is a higher chance of the upper interior glass pane's breaking as shown in Fig. 6. Hot gases would act at the exterior pane first due to momentum of ceiling jet. It would then detach from the exterior pane due to unbalanced air entrainment. Eventually hot gases would adhere to the interior pane.

But for narrow air-cavity depth of $0.5 \mathrm{~m}$, hot gases would flow up as a channel flow, giving high chance of breaking the interior pane.

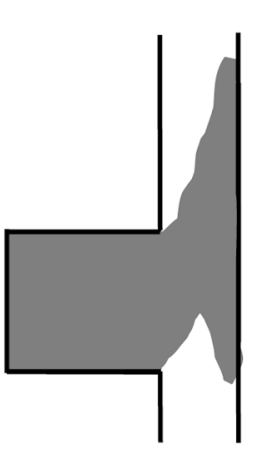

Wall jet, upper area affected more

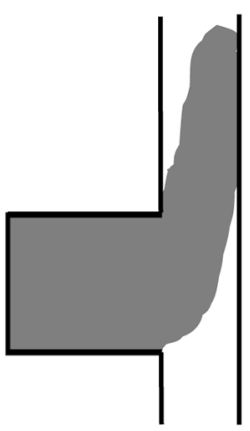

Moved up

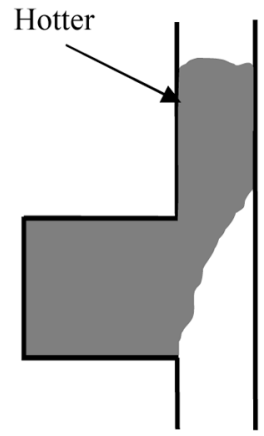

Channel flow

a) Very narrow cavity depth

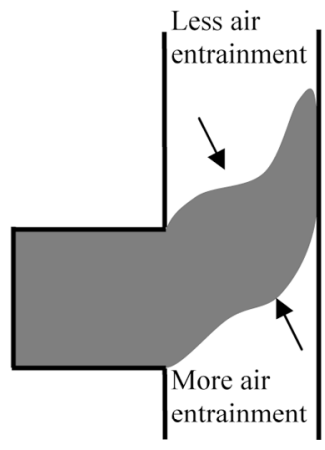

Acting at exterior pane

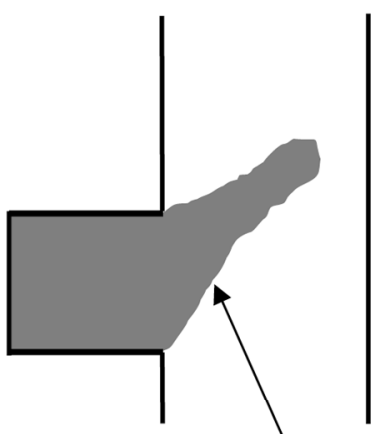

Range not far if ceiling jet momentum not strong enough

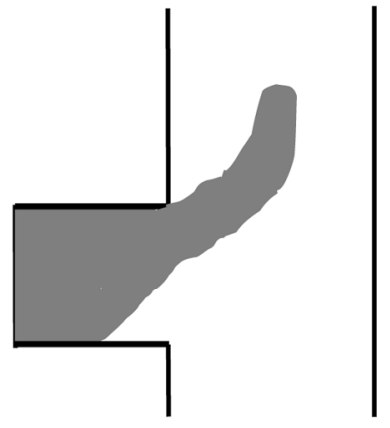

Started moving up more

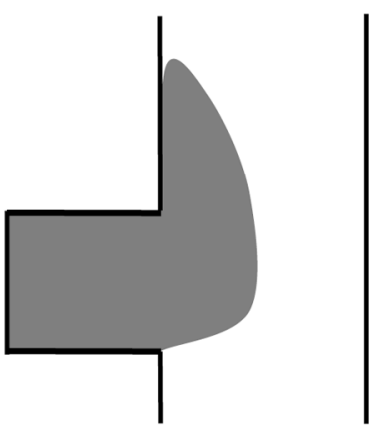

Attached to the interior pane
Attached to the interior pane

b) Narrow cavity depth

c) Very wide cavity depth

Fig. 18. Possible flame spread in double-skin façade 
In the case of very wide air cavity of depth over $2 \mathrm{~m}$ as in a single-skin façade, hot gas will be attached to the upper faces as explained before in the review.

Three possible fire hazards can be deduced for this identified scenario from this CFD study. These are on having higher air temperatures adjacent to the interior glass pane than the exterior pane; vertical channel flow of hot smoke and upward flame; and fire sources jumping up. A summary is shown in Fig. 18 on DSF with very narrow cavity depth less than $0.5 \mathrm{~m}$, narrow cavity depth of $1 \mathrm{~m}$ to $2 \mathrm{~m}$, and very wide cavity depth over $2 \mathrm{~m}$. All observations suggested that fire hazard in a DSF should be watched carefully. Appropriate fire safety provisions should be provided. The CFD predictions above are just preliminary observations. Experiments were carried out to demonstrate the above deduction and reported separately.

Onsetting flashover to have a fire with long duration in the room adjacent to DSF depends on the ventilation provisions and fire load stored inside. As surveyed in Hong Kong, fire load density used to be high for buildings in dense urban areas. Breaking the interior glass next to the DSF would spread smoke and heat to the façade cavity. Cavity depth is a key factor on fire hazard. Building height is also important because fire can spread up the whole DSF. Breaking the interior glass at the upper room would spread heat and smoke inside the room. Another flashover fire is then resulted at that room. The fire appears to jump up from the rooms sequentially. Vertical channel flow due to stack effect and buoyancy of hot gases would be hazardous. In view of the above numerical results, hazard at DSF depends on the fire load, cavity depth and building height.

\section{Acknowledgment}

The author would like to thank Professor K. Steemers for supervising the $\mathrm{PhD}$ project at Cambridge.

\section{References}

Alpert, R. L. 2003. Ceiling jet flows, in SFPE Handbook of Fire Protection Engineering. $3^{\text {rd }}$ edition. Section 2, Chapter 2. Society of Fire Protection Engineers, Boston, MA, USA and National Fire Protection Association, Quincy, MA, USA, 56-68.

Bong, F. N. P. 2000. Fire spread on exterior walls. Master's thesis. New Zealand: University of Canterbury. 206 p.

BS EN 13501-2:2007+A1:2009. 2008. Fire classification of construction products and building elements - Part 2: Classification using data from fire resistance tests, excluding ventilation services. British Standards Institution, UK. 84 p.

Chow, C. L. 2009. Assessment of fire hazard on glass buildings with an emphasis on double-skin façades. PhD Theses. UK: University of Cambridge. $100 \mathrm{p}$.

Chow, C. L.; Chow, W. K. 2009a. Fire safety aspects of refuge floors in supertall buildings with computational fluid dynamics, Journal of Civil Engineering and Management 15(3): 225-236. doi:10.3846/1392-3730.2009.15.225-236

Chow, C. L.; Chow, W. K. 2009b. A brief review on applying computational fluid dynamics in building fire hazard assessment, in I. Søgaard, H. Krogh (Eds.). Fire Safety. Nova Science Publishers, 43-68.
Chow, W. K. 1995. Use of computational fluid dynamics for simulating enclosure fires, Journal of Fire Sciences 13(4): 300-334. doi:10.1177/073490419501300405

Chow, W. K. 2003. Fire safety in green or sustainable buildings: Application of the fire engineering approach in Hong Kong, Architecture Science Review 46(3): 297-303.

Chow, W. K.; Hung, W. Y. 2006. Effect of cavity depth on smoke spreading of double-skin façade, Building and Environment 41(7): 970-979. doi:10.1016/j.buildenv.2005.04.009

Chow, W. K.; Li, S. S.; Gao, Y.; Chow, C. L. 2009. Numerical studies on atrium smoke movement and control with validation by field tests, Building and Environment 44(6): 1150-1155. doi:10.1016/j.buildenv.2008.08.008

Chow, W. K.; Zou, G. W. 2009. Numerical simulation of pressure changes in closed chamber fires, Building and Environment 44(6): 1261-1275. doi:10.1016/j.buildenv.2008.09.016

Courant, R.; Friedrichs, K.; Lewy, H. 1967. On the partial difference equations of mathematical physics, IBM Journal of Research and Development 11(2): 215-234. doi:10.1147/rd.112.0215

Ding, W. T.; Hasemi, Y.; Yamad, T. 2005. Smoke control using a double-skin façade, in The 8th International Symposium on Fire Safety Science, Tsinghua University, Beijing, China, 18-23 September, 2005. International Association for Fire Safety Science, Paper SC-2.

Galea, E. R.; Berhane, D.; Hofmann, N. A. 1996. CFD analysis of fire plumes emerging from windows with external protrusions in high rise buildings, in The International Fire Science and Engineering Conference: Interflam '96, 2628 March, 1996, Cambridge, UK, 835-839.

Glass and Glazing Federation. 1978. Glazing manual. London, UK [accessed 9 July 2010]. Available from Internet: $<$ http://www.ggf.co.uk/>.

Hassani, S. K. S.; Shields, T. J.; Silcock, G. W. 1995. Thermal fracture of window glazing: Performance of glazing in fire, Journal of Applied Fire Science 4(4): 249-263.

Himoto, K.; Tsuchihashi, T.; Tanaka, Y.; Tanaka, T. 2009a. Modeling the trajectory of window flames with regard to flow attachment to the adjacent wall, Fire Safety Journal 44(2): 250-258. doi:10.1016/j.firesaf.2008.06.007

Himoto, K.; Tsuchihashi, T.; Tanaka, Y.; Tanaka, T. 2009b. Modeling thermal behaviors of window flame ejected from a fire compartment, Fire Safety Journal 44(2): 230240. doi:10.1016/j.firesaf.2008.06.005

Jackman, L.; Finegan, M. 2001. Facades on multi-storey buildings: A fire risk assessment guide. Report LPR 18. Fire Protection Association, Moreton in Marsh, Gloucestershire, UK. 15 p.

Klopovic, S.; Turan, ÖF. 1998. Flames venting externally during full-scale flashover fires: two sample ventilation cases, Fire Safety Journal 31(2): 117-142. doi:10.1016/S0379-7112(97)00065-9

Kumar, S. 2009. Fire modelling with computational fluid dynamics. DG 511. BRE Press, Building Research Establishment, UK. 12 p.

Kumar, S.; Cox, G.; Thomas, P. H. 2010. Air entrainment into balcony spill plumes, Fire Safety Journal 45(3): 159-167. doi:10.1016/j.firesaf.2010.02.001

Law, M. 1978. Fire safety of external building elements - the design approach, Americas Iron Steel Engineering Journal Second Quarter, 59-74. 
Lax, P. D. 1967. Hyperbolic difference equations: A review of the Courant-Friedrichs-Lewy paper in the light of recent developments, IBM Journal of Research and Development 11(2): 235-238. doi:10.1147/rd.112.0235

Loncour, X.; Deneyer, A.; Blasco, M.; Flamant, G.; Wouters, P. 2004. Ventilated double facades-Classification and illustration of façade concepts. Belgium, 2004 [accessed 9 July 2010]. Available from Internet: <http://www.bbri.be/ activefacades/new/index.cfm?cat=3_concepts $>$.

Lstiburek, J. W. 2008. Why green can be wash, ASHRAE Journal 50(11): 28-36.

Ma, T. G.; Quintiere, J. G. 2003. Numerical simulation of axisymmetric fire plumes: accuracy and limitations, Fire Safety Journal 38(5): 467-492. doi:10.1016/S0379-7112(02)00082-6

Mawhinney, R. N.; Galea, E. R.; Hoffmann, N.; Patel, M. K. 1994. A critical comparison of a PHOENICS based fire field model with experimental compartment fire data, Journal of Fire Protection Engineering 6(4): 137-152. doi:10.1177/104239159400600401

McGrattan, K. B. 2006. Fire Dynamics Simulator (Version 4) Technical reference guide. NIST Special Publication 1018, National Institute of Standards and Technology, US Department of Commerce, USA. 109 p.

McGrattan, K. B.; Forney, G. P. 2005. Fire Dynamics Simulator (Version 4) - User's guide. NIST Special Publication 1018, National Institute of Standards and Technology, US Department of Commerce, USA. 90 p.

Morris, B. 1999. Fire spread in multi-storey buildings with glazed curtain wall facades. Loss Prevention Council,
Borehamwood, England. 35 p.Oleszkiewicz, I. 1989. Heat transfer from a window fire plume to a building façade, in Proc. of Winter Annual meeting of the American Society of Mechanical Engineers, San Francisco, California, USA, HTD, 123: 163-170.

Oesterle, E.; Lieb, R.; Lutz, M.; Heusler, W. 2001. Double-skin facades: integrated planning. Prestel Publishing. 2008 p.

Satoh, K.; Kuwahara, K. 1991. A numerical study of windowto-window propagation in high-rise building fires, in Proc. of the Third International Symposium on Fire Safety Science, 7-12 July, 1991, Edinburgh, UK, 355-684.

Schaelin, A.; Van der Maas, J.; Moser, A. 1992. Simulation of airflow through large openings in buildings, ASHRAE Transactions 98(2): 319-328.

Seigel, L. G. 1969. The projection of flames from burning buildings, Fire Technology 5(1): 43-51. doi:10.1007/BF02591612

Shields, T. J.; Silcock, G. W. H.; Flood, M. 2002. Performance of a single glazing assembly exposed to a fire in the centre of an enclosure, Fire and Materials 26(2): 51-75. doi:10.1002/fam.783

Sinclair, R.; Phillips, D.; Mezhibovski, V. 2009. Ventilating façades, ASHRAE Journal 51(4): 16-27.

Streicher, W. (Leader), et al. 2005. BESTFAÇADE: Best Practice for double skin façades - Literature. EIE/04/135/S07.38652 [Accessed 9 July 2010]. Available from Internet: <www.bestfacade.com $>$.

Thomas, P. H.; Law, M. 1973. The projection of flames from buildings on fire, Fire Prevention Science and Technology 10: 19-26.

\section{SKAITINIS DŪMŲ SKLIDIMO DVIGUBO FASADO ERTMĖJE TYRIMAS}

\section{L. Chow}

Santrauka

Dvigubas fasadas yra ekologiškas architektūrinis sprendimas. Tačiau dvigubas fasadas yra problemiškas gaisrinės saugos požiūriu. Nagrinėjamas scenarijus, kai greta dvigubo fasado esančioje patalpoje įvyksta gaisro pliūpsnis. Dvigubo fasado ertmėje gali būti uždaryti karštis ir masè. Taikomi skaitmeninès skysčiu dinamikos metodai nustatyti, kaip iš patalpos, kurioje i̇vyksta gaisro pliūpsnis, oras ir degimo produktai išstumiami i dvigubo fasado ertmę. Modeliuoti naudojama kompiuteriné programa, parengta JAV Nacionaliniame standartų ir technologijos institute. Nagrinejjami trys dvigubų fasadų sprendimai. Atliekamas detalus pirmojo sprendimo fasado modeliavimas siekiant suprasti gaisro lemiamą aerodinamiką penkių aukštų fasade, kai gaisras kyla trečiame aukšte. Modeliuojamas karštų dujų sklidimas iš fasado ertmės viršaus teigiant, kad gaisro išskiriama šiluma yra $1 \mathrm{MW}$ ir $5 \mathrm{MW}$. Ertmès plotis imamas lygiu $0,5 \mathrm{~m}, 1,5 \mathrm{~m}$ ir $2 \mathrm{~m}$. Nustatomi trys liepsnos sklidimo iš dvigubo fasado etapai. Gauti rezultatai leidžia daryti išvadą kad platesni fasadai yra pavojingesni, nes didina viršutinių stiklo diskų dužimo tikimybę. Aukštesni antro ir trečio sprendimo fasadai naudoti tirti, kaip karštis ir masė juda vertikalia fasado ertme. Skyrèsi šių fasadų ertmès plotis. Abu fasadai buvo $24 \mathrm{~m}$ aukščio, tačiau skyrèsi gaisro patalpos aukštis. Buvo palygintas vertikalusis temperatūros pasiskirstymas dvigubo fasado ertmèje.

Reikšminiai žodžiai: dvigubas fasadas, oro ertmè, dūmų sklidimas.

Cheuk Lun CHOW. Graduated with a PhD degree in 2009 from the Department of Architecture, Wolfson College, University of Cambridge, UK. Her PhD project is on fire hazard of glass buildings and double-skin façades. Her research interests include the application of Computational Fluid Dynamics in simulating fires, natural ventilation, glass façade fires, and fire safety in green buildings. 